\title{
Remodelaciones urbanas en conjuntos históricos y sus entornos
}

\author{
Javier Bermúdez Sánchez \\ Profesor Titular de Derecho Administrativo \\ Universidad Autónoma de Madrid
}

\begin{abstract}
SUMARIO: I.- LA DELIMITACIÓN DEL ENTORNO DE CONJUNTO HISTÓRICO Y DE CIUDADES PATRIMONIO DE LA HUMANIDAD. a) Delimitación de los entornos. b) Zona de amortiguamiento en las ciudades patrimonio de la humanidad. II.- ACTUACIONES URBANAS PREVIAS A LA APROBACIÓN DE PLAN ESPECIAL DE PROTEGCIÓN. a) Sustitución de inmuebles y alteración de la edificabilidad o de las alineaciones en conjuntos históricos sin plan especial. b) La modificación de entornos previa a plan especial. c) Exigencia de doble autorización en el conjunto y su entorno: concurrencia de la competencia municipal y de la comunidad autónoma (o isla). d) La solución de discrepancias entre las dos Administraciones competentes. e) Motivación de las resoluciones del municipio y de la comunidad autónoma o isla. III.- REMODELACIONES CON RESPETO A LA ESTRUGTURA URBANA ESTABLEGIDAS EN PLANES ESPECIALES DE PROTEGCIÓN. a) Contenido general y límites de los planes especiales: la modificación de alineaciones. b) La modificación de la estructura urbana en los planes especiales de conjuntos históricos. b, 1) La posición original del Tribunal Supremo de estricta inalterabilidad de las alineaciones en conjuntos históricos. b, 2) Modificación de alineaciones en aplicación de legislación autonómica confirmada por el Tribunal Supremo. c) La coordinación de competencias municipales y de la comunidad autónoma o isla en la aprobación de planes especiales. d) La articulación de competencias en los supuestos de sustitución de inmuebles una vez aprobado el plan especial del conjunto; la autorización en zonas arqueológicas o paleontológicas, monumentos y sus entornos. IV.- VALORACIÓN FINAL
\end{abstract}

\section{RESUMEN:}

La protección urbanística de los centros históricos de las ciudades es una de las cuestiones más acuciantes en nuestro Derecho, y la solución, de momento, es confusa, como se observa en el reciente caso del Cabanyal en Valencia y en sentencias judiciales diversas. Se plantean dos dudas esencialmente. En primer lugar cuál es la interpretación de la regulación estatal, entre otros del art. 21 LPHE (16/1985), si se permiten o no modificaciones de alineaciones urbanas y en qué supuestos y condiciones. En segundo lugar, como es el 
caso, si la legislación de las "Comunidades Autónomas" puede establecer una regulación distinta, más permisiva, o si esto vulnera la regulación estatal concurrente en materia de cultura (art. 149. 2 de la Constitución). El estudio de la legislación, jurisprudencia y doctrina, permite una lectura precisa del supuesto. A juicio del autor, la legislación de las Comunidades Autónomas en las leyes generales de protección del patrimonio cultural es conforme a la Constitución, aunque requiere una interpretación matizada. En concreto, no se considera constitucional la solución en el caso del Cabanyal en Valencia: una Ley de Valencia de caso único de 2010, declara que es legal tal actuación de remodelación urbana -aunque es evidente que perjudica la estructura histórica-. Esto debería llevar consigo la declaración de inconstitucionalidad por parte del Tribunal Contitucional por aplicación de la regla del Derecho prevalente del Estado (art. 149. 3 de la Constitución) en un supuesto de validez de ambas normas.

\title{
Palabras clave:
}

Ciudades históricas; estructura urbana; trama urbana; trama histórica; patrimonio cultural; patrimonio histórico-artístico; conjuntos históricos; alineaciones urbanas; remodelación urbana; competencias normativas concurrentes; regla de prevalencia del derecho estatal; cultura; Comunidades Autónomas.

\begin{abstract}
:
Protecting urban historic centers is one of the most pressing legal issues, and the solution at the moment is unclear, as the recent "Cabanyal (Valencia) case", as well as other decisions, has proven. Those cases raise essentially two questions. Firstly, what is the interpretation that should be given to state regulation, including art. 21 LPHE (16/1985), if changes or urban alignments are forbidden. In what circumstances and conditions? Second, as is the case, if the law of the "autonomous" regulation can establish a different, more permissive status, or if it violates the concurrent state regulation in cultural matters (art. 149. 2 of the Constitution). We are in disposition of giving an answer to such questions by means of the analysis of the law, the courts' legal doctrine and the opinion of legal scholars. It is the author's contention that the law of the Autonomous Communities is compatible with the Constitution, under certain interpretation. Such reading does not permit the solution given in the Cabanyal case. The Valencia law, which was at stake, should have been declared unconstitutional.
\end{abstract}

Key words:

Historic cities, urban structure, urban fabric, historic fabric, cultural heritage, historical and artistic heritage, historic areas, alignments urban, urban 
renewal, concurrent legislative powers, rule of prevalence of state law, culture, autonomous regions.

La conservación de los centros históricos plantea una disyuntiva: la protección a ultranza de los edificios y la trama urbana, y la mejora del hábitat que permita apreciar y disfrutar de una realidad inalterada. En la Carta Internacional para la conservación de ciudades históricas y áreas urbanas históricas ("Carta de Washington”, 1987), del ICOMOS (Consejo Internacional de Monumentos y de Lugares de Interés Artístico e Histórico) se vierten ambos criterios de protección (conservación de la forma urbana y mejora del hábitat) mediante intervenciones con prudencia, método y rigor, en atención a cada caso en particular. En un ámbito global, la protección del medio ambiente ya ha incorporado este conocido principio general de desarrollo sostenible, que debe ponderar en atención al grado de protección de los bienes en concreto, y en un contexto más próximo el más reciente Convenio Europeo del Paisaje de 20 de octubre de 2000 (ratificado el 6-11-2007, BOE 5-2-2008) se refiere a la relación equilibrada y armoniosa entre las necesidades sociales, la economía y el medio ambiente. Estos criterios vertebran una actuación prudente en el ámbito de los conjuntos históricos declarados, cuyos valores culturales exigen una especial cautela si no una protección absoluta. Lejos de este planteamiento quedan los intentos recurrentes de eliminar antiguas construcciones y sustituirlos por centros comerciales, por ejemplo, o cualquier otra edificación de carácter puramente lucrativa. La precisión que se quiera dar al nivel de protección nunca podrá implicar una vulneración de la premisa de protección del conjunto histórico, por lo que esas actuaciones urbanísticas salvajes encubiertas en modelos especulativos de "rehabilitación" quedan excluidas como punto de partida de la discusión de este artículo ${ }^{1}$.

En determinados casos concretos, esencialmente relacionados con la existencia de infraviviendas y carencia de dotaciones públicas en centros históricos, podrá

1 Ténganse presentes los elocuentes términos de J. LÓPEZ JAÉN "Sobre los conjuntos históricos españoles", en la revista Ciudad y Territorio: estudios territoriales, no 85, 1990 (3), pp. 57-66, en concreto p. 58: “... La simple y burda especulación se sustituye por una especulación de lo histórico-artístico que quiere ser refinada y culta pero no puede...". A propósito de esta ponderación, desde una perspectiva técnica, M. GARCÍA NART, "Planeamiento urbanístico y definición del centro histórico" en Actas del primer Seminario de Derecho, Urbanismo y Patrimonio, Sevilla 1998, 1999, pp. 41-60, en concreto pp. 52-53, propone que el legislador y el planificador diferenciaran determinaciones vinculantes e indicativas, para evitar modelos excesivamente rígidos que impidan la rehabilitación del patrimonio, pero que prevenga, a su vez, la desregulación y pérdida de control, en sentido similar a lo propuesto por LÓPEZ JAÉN, ob. cit. 
ser imprescindible, en atención asimismo a la protección del modo de vida y hábitat que se desarrolla en ese conjunto, de la integración del área y sus vecinos en el resto del núcleo en condiciones adecuadas, que se lleve a cabo alguna intervención que atienda a tales problemas ${ }^{2}$. Ahí es donde se enmarcan los supuestos de sustitución de inmuebles y modificación de alineaciones tratadas en este estudio.

La legislación de patrimonio cultural o histórico (como se prefiera) ha apreciado tal circunstancia como supuesto compatible y objetivo propio de la conservación del conjunto. Los matices legales (regulación estatal y de las Comunidades), sin embargo, han dado lugar a una jurisprudencia que en ocasiones sólo con dificultad es capaz de atemperar el objetivo de protección a ultranza o absoluta de los centros históricos con la mejora del mismo. De hecho tiene que atender a la difícil redacción de la misma Ley 16/1985 de Patrimonio Histórico Español -en adelante LPHE-, en la que se establecen las siguientes cautelas: en primer término excluye absolutamente estas remodelaciones (alteración de alineaciones o edificabilidad, ni agregaciones) antes de que se haya aprobado el plan especial (u otro instrumento de planeamiento equivalente) -art. 20.3 LPHE-; y sólo admite la posibilidad de que un plan especial articule remodelaciones urbanas en conjuntos históricos en consideración a circunstancias excepcionales (lo que excluye terminantemente las referidas rehabilitaciones especulativas), siempre que permitan una mejora de sus relaciones con el entorno territorial urbano o eviten usos degradantes para el propio conjunto (art. 21. 2 LPHE); y también ciñe las sustituciones de inmuebles a los casos en que contribuyan a la conservación general del carácter del conjunto, manteniendo las alineaciones urbanas existentes (art. 21.3 LPHE). La formulación de estas prescripciones, ha planteado dudas en la jurisprudencia, en los supuestos de sustitución de inmuebles (si son o no admisibles antes de que exista plan especial, y circunstancias excepcionales posteriores al plan), el de alteración de alineaciones (aunque la haya previsto el plan especial ante la insistencia del legislador de que se mantengan las alineaciones en el art. 20.3 y en el apdo. 3, del art. 21, LPHE), y en el respeto a la prohibición de incrementar la edificabilidad (si es la existente o la prevista en el planeamiento general aprobado).

Sobre las políticas de rehabilitación desde la perspectiva urbanística, vid. Cursos sobre patrimonio histórico, 5. Actas de los XI cursos monográficos sobre el patrimonio histórico, M. Iglesias Gil Ed., pp. 313-440, con diversos casos de planeamiento especial en centros históricos de Valencia, valle de Cabuérniga, Vitoria-Gasteiz, Bilbao y Lyón, entre otros; y Francisco POL: "La cultura y la política de la recuperación de los centros históricos" en Urbanismo y patrimonio histórico, 1999, pp. 223-252. Sobre la disyuntiva entre la mejora o la conservación de las ciudades, S. GONZÁLEZ-VARAS IBÁÑEZ, La rehabilitación urbanística, 1998. 
Posiblemente, ante la mencionada insistencia del legislador, la aclaración más necesaria se refiera a si es admisible la modificación de alineaciones. Una legislación autonómica o, como debería denominarse, comunitaria (de las comunidades autónomas), más precisa, ha permitido eventualmente una mejora en la interpretación de los términos de la prescripción de la legislación estatal, pues incluye la alteración de alineaciones en los supuestos de remodelación urbana con plan especial, como se verá. Esta solución de las comunidades autónomas deberá someterse en primer término al respeto a la legislación estatal, en su caso, y, además, cómo se resolverá tal actuación de remodelación con modificación de alineaciones en las Comunidades con previsión similar a la legislación estatal.

Asimismo, todas las cautelas establecidas en el ordenamiento jurídico para la protección y conservación de conjuntos históricos, deben considerarse en las actuaciones en sus entornos ${ }^{3}$, precisando cuáles les son de aplicación. Este estudio debe mencionar además la regulación especial establecida para las $z 0^{-}$ nas de amortiguamiento de las ciudades declaradas patrimonio de la humanidad por la UNESCO ${ }^{4}$, que no tienen por qué coincidir con los entornos de conjuntos históricos.

El tratamiento de estas cuestiones se ha plasmado ya en numerosas sentencias del Tribunal Supremo (TS) y Tribunales Superiores de Justicia (TSJ), que junto a las soluciones en la legislación de las comunidades autónomas ofrecen un análisis novedoso. Como se expondrá, hay además una cierta evolución o precisión en la jurisprudencia del Tribunal Supremo acerca de la modificación de alineaciones en conjuntos históricos con plan especial, que se pronuncia a raíz de la regulación de las comunidades autónomas, y merece ser destacada.

Desde una perspectiva histórico-artística, vid. CASTILLO RUIZ, J.: El entorno de los inmuebles de interés cultural, 1997.

Sobre la evolución en la legislación internacional, europea y nacional, vid. M. BASSOLS COMA: "Los conjuntos históricos: su concepto en los ordenamientos jurídicos internacional y autonómico" en Nuevas perspectivas del régimen local. Estudios homenaje al profesor Boquera Oliver, Climent Barberá y Baño León, coord., 2002, pp. 1281 ss. 


\section{LA DELIMITACIÓN DEL ENTORNO DE CONJUNTO HISTÓRICO Y DE CIUDADES PATRIMONIO DE LA HU- MANIDAD}

\section{a) Delimitación de los entornos}

Las cuestiones planteadas sobre modificación de alineaciones y demolición de inmuebles, se suscitan tanto sobre áreas de conjunto histórico como de su entorno ${ }^{5}$. Como premisa, entonces, se debe justificar si el régimen jurídico requiere diferenciar entre supuestos ubicados en un conjunto histórico y en su entorno, y en concreto, cómo se realiza la delimitación de los entornos de los conjuntos históricos o de otro bien de interés cultural (en adelante, BIC). Se avanza que el tratamiento jurídico de los denominados entornos comparte con matices el régimen jurídico del inmueble declarado BIC, y en concreto, por lo que trata este primer epígrafe, sí se debe declarar el entorno junto al resto del conjunto, esto es, comparte su procedimiento de declaración, como se desprende del Ordenamiento y recoge la jurisprudencia.

La delimitación del entorno se debe contener en la propia declaración del BIC, como se establece en los arts. 11. 2 (la resolución que declara el inmueble BIC delimitará su entorno), y 17 (en la tramitación del conjunto histórico), de la LPHE. En algún caso podría haberse declarado el conjunto sin delimitación expresa del entorno o en otros, la conveniencia de ampliar o limitar el mismo. En ambos supuestos, de acuerdo con tal previsión estatal, la legislación de las comunidades autónomas ha preceptuado que se atenderá al mismo trámite que la declaración ${ }^{6}$.

Vid. Ma R. ALONSO IBÁÑEZ, Los espacios culturales en la ordenación urbanística, 1994, pp. 77-101, que con base en la jurisprudencia del Tribunal Supremo destaca la diferente intensidad en su protección, su régimen jurídico, y supuestos de delimitación, algunos de declaraciones anteriores a la LPHE en interpretación del Decreto de 22 de julio de 1958, en defecto entonces de regulación autonómica.

Así en el art. 11 de la Ley 12/1998 del Patrimonio Histórico de las Islas Baleares, en adelante LPHIB; en otros casos se ha determinado también una delimitación cautelar para los inmuebles protegidos que no lo hubieran establecido al no preverlo la regulación anterior, de 50 m. en suelos urbanos y $200 \mathrm{~m}$. en suelos urbanizables o no urbanizables, en tanto no se revise conforme al procedimiento de modificación de la declaración de BIC, en la D.A. 4. ${ }^{a}$ Ley 14/2007 de protección del Patrimonio Histórico Andaluz, en adelante LPHAnd. Se establecen numerosos factores a tener en cuenta en la delimitación del entorno, en el Anexo I, A, III del Decreto 37/2007 de 19 de abril por el que se aprueba el Reglamento de Protección del Patrimonio Cultural de Castilla y León, RPCGyL: elementos distorsionantes (ocultan el bien, pertur- 
Esta obligación se relaciona en la jurisprudencia ${ }^{7}$. Así la Sentencia del Tribunal Superior de Justicia de Madrid (en adelante STSJ) de 17-5-2007 (rec. núm. 2462/2003) estima que es necesaria la delimitación del entorno de un inmueble BIC de la que carecía la resolución que declaraba el dolmen de Dalí situado en la plaza del mismo nombre de la ciudad de Madrid ${ }^{8}$. También se debe precisar que esa protección no puede ser dispensada más que al entorno declarado expresamente, de forma que la STSJ de Extremadura de 21-2-2003 (rec. núm. 920/2000) llegará a anular la suspensión de las obras en entorno genérico de un bien inventariado que contaban con la licencia municipal oportuna ordenada por la comunidad autónoma ${ }^{9}$. Bajo la misma premisa de necesidad de

ban su contemplación; alteran su carácter y significación; incompatibilidad de uso); planeamiento existente en el municipio (plan especial; delimitación del suelo; normas subsidiarias; plan general; otros); protección física (control del mal estado de edificaciones próximas; la ordenación; control de usos; protección de espacios relacionados históricamente con el bien; control de la edificación); protección y valoración estética (identificación del bien; integración del bien en el paisaje; valoración de perspectivas estéticas consolidadas histórica o colectivamente); definición de objetivos; y delimitación física del entorno. La ausencia de regulación de los entornos de los conjuntos en la Ley del Patrimonio Cultural de Murcia, LPCMur, que sólo se refiere a los de los monumentos (entre otros art. 42), debe ser completada con la aplicación directa de los arts. 11. 2 y 17 LPHE; y la posibilidad establecida en el art. 12. 1 LPHC-LM de que sean los planes especiales los que delimiten entornos en ausencia de tal en la declaración, no casa con las mencionadas determinaciones de los arts. 11 y 17 LPHE.

En algún caso la declaración de conjunto histórico se remite a los planos adjuntos. Así la Sentencia del Tribunal Supremo (en adelante STS) 18-11-2002 (rec. $\mathrm{n}^{\circ}$ 1369/2000), en el caso del proyecto de ampliación del Museo del Prado, referida al claustro y atrio protegidos como entorno de la iglesia de San Jerónimo el Real en plano anexo al Decreto de declaración del monumento BIC de titularidad estatal en cuanto adscrito a servicio público gestionado por el Estado. Es aplicable la legislación de la Comunidad a la protección del entorno (FD 9. ${ }^{\circ}$ ), y además de forma, a mi juicio, retórica, la Sentencia citada estima que no hay destrucción ni deterioro del entorno del monumento [del atrio, que como se recordará, se encierra en un edificio en forma de cubo], ni se limita la contemplación ni perspectiva del monumento (FFDD 11. $.^{\circ}, 12 .^{\circ}$ y 13. ${ }^{\circ}$ ).

De forma que:

“... en atención a lo expuesto, la Comunidad de Madrid deberá dictar resolución acordando la protección singular que merece el entorno así entendido, en relación con los edificios circundantes de la Plaza y con aquellos otros elementos que considere integrados en ese entorno". (Fundamento de Derecho, en adelante FD, 9. ${ }^{\circ}$ Sentencia citada).

Con base en la argumentación que se ha referido:

"... Ahora bien, el entorno del "monumento", no tiene una delimitación genérica de tal forma que la Administración pueda actuar en su defensa en función de las concretas peculiaridades que 
declaración expresa del entorno de BIC, la STSJ de Andalucía de 28-6-2000 (rec. núm. 2950/1997), que a instancias de la corporación municipal, anula la resolución de la comunidad autónoma que pretende controlar las obras en un entorno genérico de las murallas de Cádiz (BIC). El Tribunal precisa (FD 4. ${ }^{\circ}$ ) que sólo al entorno delimitado "le será de aplicación el mismo régimen jurídico que corresponda al inmueble catalogado", pero en esa actuación que llevó a cabo el Ayuntamiento no estaba delimitado.

Alguna legislación de las comunidades autónomas no ha determinado la delimitación en la misma incoación, así en la valenciana como recuerda la STSJ de C. Valenciana 12-4-2006 (rec. núm. 998/2003, FD 3. ${ }^{\circ}$ ), que no determina tal exigencia en el acuerdo de incoación sino en la declaración con que concluye el procedimiento. En este supuesto se trata de una declaración de BIC como jardín botánico (categoría creada por la norma autonómica), por lo que estaría justificada la inaplicación del art. 17 LPHE (conjuntos históricos). La norma valenciana podrá ser discutida, sin embargo, en otros supuestos de entorno de conjuntos históricos, a los que no alude tampoco en este supuesto de delimitación en la tramitación de conjuntos históricos, pero en este caso deberá resolverse a favor de la determinación establecida en el art. 17 LPHE. Otra regulación de las comunidades autónomas sí ha precisado la delimitación del entorno ya desde la incoación del $\mathrm{BIC}^{10}$.

Los tribunales, además, aprecian cómo la delimitación del entorno en todo caso debe estar motivada pues se trata de ejercicio de competencias discrecionales (esto es, como margen de decisión que el legislador reconoce a la Administración) y será controlada jurisdiccionalmente, y eventualmente anulada por su insuficiencia, como determina la STSJ de Extremadura de 21-6-2001 (rec. núm. 2170/1997). El Tribunal estima que la delimitación del entorno es un "concepto jurídico indeterminado" frente a la discrecionalidad, recogien-

concurran ante cualquier actuación que pudiera considerarse lo altera... En suma y por lo que al caso de autos se refiere, no es que como entiende la Administración regional, la existencia de un Bien Patrimonial legitime la actuación en su entorno, sino que la misma declaración de Monumento en concreto, comporta una delimitación de su entorno que tiene el mismo régimen de protección; no se protege el entorno por el Monumento sino que en la protección de éste ya va incluido y delimitado y con el mismo régimen de protección. Y si ello es así, no se aduce por la Administración Autonómica que el concreto solar donde se ejecutaban las obras estuviese delimitado como entorno de la iglesia, por lo que no podía actuarse las potestades de protección... Y es que, en definitiva... el entorno es consustancial al "Monumento"..." (FD 4. ${ }^{\circ}$ Sentencia citada).

El art. 7. 4, b) LPHIB; arts. 40. 4 y 41, b) del RPCGyL. 
do así la terminología del Tribunal Supremo, a su vez procedente de la tesis doctrinal que diferencia el supuesto de discrecionalidad (en el que los tribunales sólo pueden anular pero no sustituir la decisión que corresponde según el legislador a la Administración que debe elegir entre un haz de posibles soluciones, de forma que el poder judicial no es competente para realizar tal elección), y el de los "conceptos jurídicos indeterminados" en los que se podría anular y además sustituir la decisión errada, pues sólo existiría una única solución ${ }^{11}$, lo que hace concluir al Tribunal, que, en estos casos de conceptos jurídicos indeterminados con una única solución, el deber de motivación resultaría de especialísima transcendencia. La Administración debe justificar la delimitación física. Sí se debe advertir que el caso resuelto por la Sentencia citada del TSJ de Extremadura de 21-6-2001 es peculiar porque ya se habían producido anteriores anulaciones en la declaración del BIC que exigía una menor superficie y el Tribunal entiende que la delimitación propuesta nuevamente con la misma extensión del entorno, pretende soslayar los anteriores pronunciamientos judiciales, pues a su juicio una reducción del BIC debería llevar consigo la de su entorno. Esto es lo que posiblemente hace que el Tribunal esté más atento al deber de motivación en la delimitación del entorno ${ }^{12}$.

En el ámbito del patrimonio histórico vid. $\mathrm{M}^{\mathrm{a}} \mathrm{R}$. ALONSO IBÁÑEZ: "Normas materiales de ordenación urbanística. A propósito de las remodelaciones urbanas en conjuntos históricos", en el Derecho Administrativo en el umbral del siglo XXI: homenaje al Profesor Ramón Martín Mateo, 2000, Sosa Wagner dir., pp. 3323-3339, en concreto p. 3326.

El Tribunal se refiere a la necesidad de motivación en los términos siguientes:

"Y es que, en definitiva, con la protección extendida al entorno del monumento lo que se pretende es el mantenimiento de las condiciones arquitectónicas que permitan mantener las características del inmueble, evitando la alteración que comportaría la existencia de elementos aledaños que perjudicaran la estética o la contemplación del mismo, como se descubre en el artículo 19. 2. ${ }^{\circ}$ de la Ley del Patrimonio. Por ello la finalidad de la actividad administrativa exigida debe estar encaminada a esa concreta finalidad, de tal forma que no nos encontramos con potestades administrativas discrecionales en que la Administración pueda optar entre varias soluciones, todas ellas válidas en Derecho, sino ante un concepto jurídico indeterminado (así lo declara la STS 21-11-2000) que la Administración deberá integrar mediante el justo equilibrio entre la salvaguarda del Bien a proteger y la fuerte limitación que la declaración comporta para los propietarios colindantes con el mismo, que se ven afectados en su patrimonio en justificación del interés general que la declaración supone. Por ello adquiere una especialísima trascendencia para el control de la decisión administrativa su motivación que permitirá controlar el acierto, y por ello la legalidad, de la solución adoptada" (FD 3. ${ }^{\circ}$ Sentencia citada).

Y concluye en el caso concreto con una crítica a la justificación del entorno en el informe del Jefe de Servicio de Patrimonio Histórico Artístico que refiere la inexistencia de normas que indiquen parámetros para delimitar entornos, lo que, a juicio del Tribunal: 
En definitiva, la declaración de los entornos debe contenerse en la declaración del BIC a tenor de la regulación vigente desde 1985 (art. 11. 2 LPHE), si bien en atención a legislación específica de las comunidades autónomas, es factible que se lleve a cabo en una resolución posterior pero con el mismo procedimiento que el de declaración de BIC.

\section{b) Zona de amortiguamiento en las ciudades patrimonio de la hu- manidad}

La delimitación de un entorno o del conjunto histórico con base en la regulación estatal y de las comunidades autónomas no tiene por qué coincidir, respectivamente con la declarada o con su zona de amortiguamiento, en la ciudad Patrimonio de la Humanidad ${ }^{13}$, declarada conforme a la Convención para la Protección del Patrimonio Mundial Cultural y Natural (París, 1972), pues son textos independientes, como se indica en las Directrices Prácticas para la aplicación de la Convención del Patrimonio Mundial ${ }^{14}$. La Convención de 1972 prevé además la eventual declaración en ausencia de zona de amortiguamiento si se justifica por qué no es necesaria (directriz 106) y la modificación de esta zona, previa aprobación del Comité del Patrimonio Mundial (directriz 107).

“... no contiene una sola razón técnica que aconseje mantener el entorno en la forma que se recogía en el anterior Decreto, pues... serán las circunstancias de cada supuesto las que impondrán, desde el punto de vista de las exigencias que la norma impone, esa zona de protección contigua al monumento, pero avaladas por razones físicas que aconsejen la protección, razones que se echan de menos en el informe que se menciona..." (FD 3. . Sentencia citada).

También hay que destacar una argumentación previa en este Fundamento de Derecho 3. ${ }^{\circ} \mathrm{de}$ la Sentencia citada. El Tribunal recuerda la obligatoriedad de declarar el entorno del BIC, como ya se ha analizado aquí supra en otros casos, y parte en primer término de la necesidad de que en ese caso de monumento BIC, el plan especial de protección del área afectada armonice no sólo el bien afectado por la declaración sino también su entorno "mediante una previsión de la zona en su globalidad". Esta original afirmación que impone un plan especial global para el BIC y su entorno, resulta relevante, pero tal vez deba ser circunscrita al supuesto que trata, al entorno de un bien singular, monumento, como en este caso, o jardín, o sitio, todos BIC, pero tal vez no aplicable a otras figuras como pueda ser la del entorno del conjunto histórico BIC o zona arqueológica BIC, que podrían ser objeto de planes especiales diferenciados, que abarquen la totalidad del conjunto, o de un solo plan especial.

Alcalá de Henares, Ávila, Cáceres, Cuenca, Ibiza, Mérida, Úbeda y Baeza, Córdoba, el Albaicín en Granada, Salamanca, Santiago de Compostela, San Cristóbal de La Laguna, Segovia, Tarragona, Toledo.

De acuerdo con la directriz 102: "los límites del bien propuesto podrán coincidir con una o varias zonas protegidas existentes o propuestas, como un parque nacional, una reserva natural 


\section{ACTUAGIONES URBANAS PREVIAS A LA APROBACIÓN DE PLAN ESPEGIAL DE PROTEGGIÓN}

La segunda de las cuestiones trata de precisar las posibilidades de sustitución de inmuebles y modificación de alineaciones antes de la aprobación del plan especial de protección ${ }^{15}$, tanto en el conjunto como en su entorno, y en especial, la coordinación de competencias necesaria.

\section{a) Sustitución de inmuebles y alteración de la edificabilidad o de las alineaciones en conjuntos históricos sin plan especial}

En principio las remodelaciones urbanas sólo se realizarán de acuerdo con el art. 21. 2 LPHE a través del plan especial de protección, y hasta su aprobación definitiva, como preceptúa el art. 20. 3 LPHE, en todo caso, no se permitirán alineaciones nuevas, alteraciones en la edificabilidad, parcelaciones ni agregaciones, como reitera en general la legislación de las comunidades autónomas ${ }^{16}$, salvo el art. 35 de la Ley del Patrimonio Cultural (en adelante LPC) de Cataluña (Cat) LPCCat, el art. 12 LPHC-LM (Castilla-La Mancha), art. 31 LPHAnd y la legislación valenciana (art. 39).

o una reserva de biosfera o un barrio histórico protegido. Si bien estas áreas de protección pueden abarcar varias unidades de gestión, es posible que sólo algunas de esas zonas cumplan los criterios de inscripción".

Sobre los efectos de la declaración de BIC y en la fase previa a la aprobación del plan especial, vid. M. BASSOLS COMA, "Instrumentos legales de intervención urbanística en los centros y conjuntos históricos", Revista de Derecho Urbanístico n 118, 1990, pp. 13-51, en concreto, pp. 36-39.

En los mismos términos prohibiendo la alteración de alineaciones y de edificabilidad sin plan especial, el art. 37. 2 LPHIB, art. 46. 2 Ley 3/1999, 10 de marzo, del Patrimonio Cultural Aragonés, LPCAr; art. 56 LPCAst; art. 64. 1 LPCCant; art. 42. 4 LPCGyL; art. 53. 1 LPCHARio; art. 46. 1 LPCMur; art. 37. 2 LPCNa; art.34. 2 LPHCanar; en términos más amplios el art. 42. 1 LPHEx, prohíbe obras que afecten a la armonía del conjunto en tanto no se apruebe el plan de protección, que a mi juicio, en todo caso debe incluir la inalterabilidad de alineaciones, edificabilidad, rasantes o volumen, en la extensión del art. 20. 3 LPHE, como en buena redacción establece el art. 47. 1 LPHGa; el art. 33 LPHMa excluye la alteración de edificabilidad y alineaciones en conjuntos y, expresamente, en sus entornos, sin plan especial aprobado. El art. 12 LPHC-LM resulta insuficiente: sólo determina el contenido de conservación de los conjuntos en los planes especiales. 
Los casos de Castilla-La Mancha, Cataluña y Andalucía, se podrían tratar, a mi juicio, como mera laguna legal, en cuanto no han previsto la situación previa a la aprobación de plan especial. Si se diera tal supuesto, se debería aplicar directamente el art. 20. 3 LPHE, para los conjuntos, y excluir tal cautela para los entornos, ante la falta de previsión. Hay que prestar atención a estos preceptos de la Ley de Patrimonio Cultural de Valencia LPCVa, que sí ha determinado expresamente la situación previa a plan especial, remitiéndola materialmente a la misma regulación que la del plan especial, aunque mediante autorización de la Comunidad. La permisiva LPCVa (a mi juicio inconstitucional en este punto), en su art. 35. 2, en ausencia de plan especial de protección, remite a la autorización del Departamento de Cultura que actuará de acuerdo con los arts. 38 y 39 LPCVa, esto es, los preceptos sobre el contenido e intervenciones conforme al plan especial ${ }^{17}$. Estos preceptos de las leyes castellano-manchega, andaluza, catalana y valenciana, a mi juicio, deben ser aplicados conforme al art. 20. 3 LPHE en estos supuestos de remodelaciones previas a la aprobación de plan especial, que implican un riesgo de pérdida de valor del conjunto antes del estudio y determinación que se articula a través del planeamiento especial. A la vista de este artículo, de la lectura conjunta del art. 35 LPCGat, art. 12 LPHC-LM, art. 31 LPHAnd, y arts. 35. 2 y 39. 2 LPGVa, en cada caso en relación con el art. 20. 3 LPHE, no parece admisible la modificación de alineaciones antes de la aprobación del plan especial de protección (o instrumento de planeamiento equivalente). La aplicación del art. 20. 3 LPHE a estos supuestos a mi juicio no resulta discutible, tampoco en atención a la jurisprudencia del Tribunal Supremo que insiste en la prohibición establecida en el art. 20. 3 LPHE de modificar alineaciones en conjuntos sin plan especial (STS 2-2-2000), y constituye norma de aplicación directa por los Ayuntamientos (STS 4-10-2001), sentencias que se exponen infra a).

En el otro supuesto, de sustitución de inmuebles antes de que se apruebe plan especial, el legislador estatal no se pronuncia. De esta imprevisión respecto a las demoliciones de inmuebles, no se deduce, a mi juicio, una prohibición. Al contrario, las normas de las Comunidades han determinado tal posibilidad, con independencia de que exista o no previo plan especial de protección ${ }^{18}$, incluso

En concreto el art. 39. 2, prevé la modificación de alineaciones y edificabilidad.

Arts. 31. 2,a) y 38 Ley 14/2007 del Patrimonio Histórico Andaluz, LPHAnd; art. 59 LPGCant; art. 40 LPCGyL; art. 45 LPCHARio; art. 36 LPCMur; art. 31 LPCNa; art. 36 LPCPV; art. 35 LPHEx; art. 41 LPHGa; art. 58 LPHCanar expresamente a falta de plan especial se podrá autorizar el derribo por el Departamento de Cultura; y art. 32. 2 LPCCat. 
en casos de normas que al tiempo reiteraban los términos de la legislación estatal. De hecho, la redacción del art. 20. 3 LPHE prohibiendo expresamente la alteración de alineaciones, agregaciones o modificación de edificabilidad, permite, a contrario, tales sustituciones de inmuebles aun sin plan especial siempre que cumplan tales limitaciones, como han determinado las comunidades autónomas ${ }^{19}$.

La jurisprudencia, que se va a comentar, ha sido bastante cauta a la hora de autorizar demoliciones si no existe plan especial aprobado, y ha llegado, incluso, a negar tal posibilidad aunque contara con autorización firme de demolición de la Comunidad, en los casos en que se impugnó licencia municipal para realizar nueva edificación cuando suponía incremento de la edificabilidad existente y en consecuencia vulneraba el art. 20. $3 \mathrm{LP}^{\circ} \mathrm{HE}$. Estas sentencias sí permiten la sustitución si no suponen incremento de edificabilidad en aplicación inmediata de la prohibición del art. 20. 3 LPHE. En todo caso, la jurisprudencia, ante la sustitución de inmuebles, alude al carácter restrictivo de las intervenciones anteriores a la aprobación de plan especial, lo que deriva en una motivación adicional. La regulación define un régimen jurídico de protección cautelar más intenso en tanto no se cumple la obligación de aprobar el planeamiento especial, esto es, se debe respetar el régimen general de intervenciones en los conjuntos (infra) y además, cautelarmente, se prohíbe la afección de las alineaciones y edificabilidad.

En primer término, se admite la sustitución excepcional de inmuebles en conjuntos sin plan especial aprobado, previa autorización de la Comunidad, siempre que no suponga alteración de edificabilidad. En este sentido alguna Sentencia confirma las limitaciones que impuso la Comunidad. Con base ya en la nueva regulación de la LPHE, y conforme al relato de hechos de la STS de 2-2-2000 (rec. $\mathrm{n}^{\circ}$ 9472/1992), la Comisión Territorial de Patrimonio Histórico impuso en la construcción de un inmueble la limitación de altura a planta baja, tres altas y ático retranqueado sin respiraderos ni sobreático, resolviendo a favor de tales limitaciones ${ }^{20}$.

Además en estos casos de demolición, como en cualquier intervención previa a plan especial, se requiere la doble autorización (por todos, art. 20. 3 LPHE), local y de la Comunidad o, en su caso, Isla, lo que requerirá atender problemas de articulación de ambas competencias, aquí infra c).

Primero, en su FD 2. ${ }^{\circ}$ se relata cómo la sentencia de instancia considera que aún así se produce alteración de edificabilidad por lo que debiera haberse denegado la autorización, lo que no pudo resolver la sentencia para no incurrir en reformatio in peius. Posteriormente el Tribunal Supremo se pronuncia sobre el fondo en el Fundamento de Derecho $5 .^{\circ}$ de forma bastante contundente:

“... A tal respecto, debe recordarse que el citado art. 20 de la Ley 16/1985 obliga a los municipios afectados a redactar un plan especial de protección u otro instrumento de planeamiento de los previstos en la legislación urbanística; y en su párrafo 3 dispone... En el presente caso 
Antes del plan especial la comunidad autónoma sí puede obligar a conservar la fachada, y ello al margen de la declaración municipal de ruina (técnica y económica ya producida), como recoge el pronunciamiento STSJ de Castilla y León 26-11-2004 (rec. n 440/2003), en la que además se prevé de nuevo para otros casos que la precisión de la autorización favorable de la administración en materia de patrimonio histórico se dará "hasta que no se aprueba el plan especial" y en tanto esto no se produce las posibilidades de intervención sobre los inmuebles son mínimas, recogiendo argumentación de la STS 26-10-1999 en la que se funda, y, en concreto, es razonable en este caso la obligación autonómica de respetar la fachada (STSJ de Castilla y León 26-11-2004 citada, en su FD 3. ${ }^{\circ 21}$ ).

Si esta STSJ de Castilla y León de 26-11-2004 sí permite la demolición al menos parcial del inmueble declarado en ruina con los condicionamientos impuestos en el informe de la comisión competente de la comunidad autónoma, hay una sentencia con pronunciamientos más contundentes en que la interpretación estricta del art. 20. 3 LPHE llevaría a la prohibición en general de sustitución de edificios, aunque los datos del caso contenidos en la Sentencia son insuficientes para poder calificarlo como mera sustitución de inmueble o supuesto en el que además, como parece lógico que debiera ser, se altera la edificabilidad. Así en la STSJ de Cantabria de fecha 5-9-1997 (rec. $n^{\circ}$ 1501/1995), se impugna la licencia mu-

las actuaciones evidencian: que el proyecto de edificio está situado en zona protegida; que supone una alteración de las alineaciones existentes; y que no [ha] sido aprobado ningún «instrumento de planeamiento» de los previstos en la legislación urbanística que pueda ampararlo. Por lo cual, resulta claro que los Acuerdos impugnados se han producido con toda corrección legal, sin que se advierta razón que autorice a invalidarlos".

A contrario, el pronunciamiento de esta Sentencia parece amparar la modificación de alineaciones con plan especial de protección del conjunto pero este obiter dictum incluye una cuestión más prolija que se comenta infra III.

Primero el Tribunal recoge la consabida jurisprudencia del Tribunal Supremo acerca de la declaración de ruina, que no determina la demolición en el caso de los bienes de interés cultural, en tanto no se haya otorgado la autorización de la Comunidad, que puede imponer la conservación en atención al interés general en defensa del patrimonio cultural. Esta argumentación lleva a admitir expresamente la demolición de inmuebles declarados -también, por tanto, en ausencia de plan especial de protección- siempre que obtuvieran la autorización del órgano con competencias en materia de cultura (FD 3..$^{\circ}$. Y en este caso concluye (en el mismo FD 3. ${ }^{\circ}$ ), ya en referencia a la situación previa a la aprobación de plan especial y la posibilidad de que se impongan obligaciones de conservación con base en la doctrina citada, que la obligación de conservar la fachada se derivaría del mismo art. 20. 3 LPHE, que al prohibir la alteración de alineaciones, edificabilidad, parcelaciones o agregaciones, que evidentemente también vinculan al Ayuntamiento, impediría la demolición integral (en tanto se aprueba el plan especial). 
nicipal que autoriza la demolición en conjunto histórico sin plan especial (al parecer según los pocos datos recogidos en la Sentencia, se trataría de una licencia de demolición parcial, reforma y reposición), que además contaba con autorización del órgano competente en patrimonio histórico de la comunidad autónoma. Esta sentencia se enfrenta en primer lugar a la alegación en contra del titular de la licencia que la consideraba inimpugnable en cuanto se trataba de una cuestión de patrimonio histórico competencia de la Comunidad cuya autorización no fue impugnada. El Tribunal, sin embargo, con base en otra STSJ de Cantabria anterior de 13-6-1994, considerando que, a pesar de que si se hubiera denegado la autorización de la Comunidad, el Ayuntamiento hubiera debido denegar a su vez la licencia, y si fuera otorgada, como en el caso, el Ayuntamiento sólo podría denegarla por motivos urbanísticos, resuelve que bastaría con la audiencia a la Comunidad (aunque la autorización no se impugnara) para que la Sala pudiera evaluar "la conformidad a Derecho de la resolución adoptada, en la medida en que su enjuiciamiento sea determinante del examen de fondo relativo al otorgamiento de la licencia" (FD 7. in fine). Tal STSJ de Cantabria de 13-6-1994 estima además (obiter dictum) que la autorización autonómica podría haber sido objeto de impugnación ya que "conceptuado o no como acto de trámite dentro del procedimiento municipal de concesión de la licencia, está sujeto a revisión jurisdiccional plena y completa, por aplicación del art. 106. 1 de la Constitución". En ausencia de plan especial, de acuerdo con la STSJ de Cantabria 5-9-1997, citada, la capacidad de decisión de la Administración urbanística ha de ser necesariamente más restrictiva, sin que se admitan licencias que justifiquen la pérdida de valores protegidos ${ }^{22}$. Y sólo se podrán autorizar intervenciones que (previa evaluación y motivación) contribuyan a la mejora o conservación del conjunto ${ }^{23}$.

"De acuerdo con estos postulados, la interpretación teleológica que cabe hacer respecto del ámbito material autorizatorio que constituye la potestad de la Administración competente, en materia de ejecución de obras de construcción, rehabilitación, demolición u otras que afecten o se proyecten sobre los bienes catalogados, ha de ser forzosamente restrictiva, pues la ausencia del Plan Especial, justificadora de aquella intervención inserta en el procedimiento de licencia, no puede justificar la pérdida, deterioro o destrucción de valores constitucionalmente protegidos, ni otorgar o consentir actuaciones que no serían lícitas si el Plan se hubiera aprobado. En suma, la falta del Plan Especial no amplía la esfera de decisión de la Administración ni ensancha las facultades, ni las hace más discrecionales, que tiene para controlar y ordenar la actividad de los particulares potencialmente afectante al campo de los bienes culturales protegidos. Antes al contrario, el régimen legal que taxativamente impone la propia Ley de 1985, la cual, además, ha de ser interpretada en términos estrictos y garantizadores de la satisfacción de los fines que la inspiran, implica una restricción material de aquellas facultades. (FD 12. ${ }^{\circ}$ ).

"A las claras se aprecia que, en tanto no se apruebe el Plan Especial, las posibilidades de intervención en los inmuebles integrantes del conjunto son mínimas, y sólo pueden consentirse, 
Si la sustitución implica incremento de la edificabilidad será anulada la licencia que le dé cobertura aun con autorización de la Comunidad. En la jurisprudencia se han expuesto diversos casos de alteración de edificabilidad, que se prohíben con base en el art. 20. 3 LPHE. Un supuesto que merece mayor detenimiento es el de la STS de 29-1-2002 (rec. no 8886/1997), que confirma una STSJ de Cantabria anulando la licencia para construir edificio que alteraba la altura, volumen y ocupación en planta del anterior. En el recurso ante el Supremo, se alega, erróneamente a mi juicio con base en el art. 21. 3 LPHE, que se trataría de una sustitución excepcional en que no se contienen restricciones respecto al volumen o edificabilidad sino sólo a las alineaciones (FD 2. ${ }^{\circ}$ ).

El error está, a mi juicio, en que tal precepto alegado en el recurso (art. 21 LPHE) define el supuesto de intervenciones en conjuntos con plan especial aprobado, en cuyo caso, sí es factible (como se verá infra, III) la sustitución con alteración de volúmenes, edificabilidad e incluso de alineaciones, pero precisamente mediante un plan especial, circunstancia que no parece que concurra en el caso. Según mi criterio, el caso debería subsumirse exclusivamente en el supuesto del art. 20. 3 LPHE, en el que, como se analiza, no es admisible la alteración de edificabilidad o volumen (además de prohibición de modificar alineaciones que en el caso no parecían afectadas). El Tribunal Supremo (FD 3. $\left.{ }^{\circ}\right)$ no entra en esa delimitación de supuestos pero confirma la sentencia de instancia que constató la modificación de altura, volumen y ocupación ${ }^{24}$.

siempre que no transgredan las prohibiciones fijadas en los preceptos transcritos, previa evaluación y motivación, que deviene un requisito fundamental, de que la actuación singular se encamina a la conservación o mejora del Conjunto. Con carácter general, pues, debe afirmarse, rotundamente, que el espacio comprendido por la declaración de Conjunto Histórico de El Sardinero, no es lícito, en modo alguno, mientras no se apruebe el reiterado Plan Especial, la realización de demoliciones, ni siquiera parciales, de los edificios singulares que integran el conjunto, aunque no posean una declaración especial o singular.

Tampoco se pueden permitir, en los términos ya vistos, las alineaciones nuevas y las alteraciones en la edificabilidad". (FD $14 .^{\circ}$ ).

En el caso, además se produce la aprobación posterior del plan especial, pero según el Tribunal esto no afectaría a la declaración de nulidad de la licencia municipal, sino a la posible legalización de las obras (FD 18. ${ }^{\circ}$.

"SEGUNDO... La entidad Atan, SA en su primer motivo contempla la infracción del artículo 21.3 de la Ley de Patrimonio Histórico Español de 25 de junio de 1985 -LPHE (RCL 1985\1547; 2916 y ApNDL 10714)-. En esta norma se aprecia claramente que la finalidad de la declaración de esos Conjuntos Históricos es el de mantenerlos en su estado actual, de tal modo que se conserve así con la mayor fidelidad posible la estructura urbana y arquitectónica exis- 
Además, esta prohibición de alteración de alineaciones y de edificabilidad, de parcelaciones y agregaciones hasta la aprobación de plan especial del conjunto es norma de aplicación directa por el propio Ayuntamiento, como determina la STS de 4-10-2001 (rec. no 1620/1997), que permite así el control de la licencia para construir un edificio de veinte viviendas y garajes "en un entorno declarado Conjunto Histórico Artístico" de Santander a pesar de que contaba con resolución favorable del órgano competente autonómico en patrimonio histórico, que no había sido impugnada. El Tribunal afirma la aplicabilidad directa del art. 20. 3 con base en otra STS de 23-11-2000 (FD 2. ${ }^{\circ}$ ) y concluye declarando la nulidad de la licencia y la demolición del edificio.

En este contexto la STSJ de Illes Balears de 4-2-2009 (rec. no 140/2008), enjuicia la legalidad de una licencia (una vez demolida una casa payesa, Ses Castellones, con autorización del Consell Insular), en conjunto histórico sin plan especial aprobado, para construir un centro comercial con incremento notable de la edificabilidad (4.133,26 metros cúbicos frente a los 614 de las edificaciones existentes). La Sentencia se pronuncia en términos similares a la STS 4-10-2001 y de la STSJ de Cantabria 5-9-1997, citadas, y se centra en la interpretación del art. 37. 2 LPHIB, con contenido similar al estudiado del art. 20. 3 LPHE.

En primer lugar el TSJ Illes Balears, considera (FD 2. ${ }^{\circ}$ ) que la declaración de conjunto con posterioridad a la redacción de las Normas Subsidiarias hubie-

tente en el conjunto, manteniéndose las características de su entorno ambiental, y por ello, precisamente, constituye una excepción a esa regla general de mantenimiento de los edificios en su estado originario, la posibilidad de sustituir tales inmuebles, aun cuando fuese parcial esa sustitución, comprendiendo sólo la sustitución de algún elemento del edificio, y desde luego, siempre que tal sustitución contribuya a la conservación general del carácter del conjunto, y con el mantenimiento a rajatabla de las alineaciones preexistentes.

TERCERO.- El referido precepto, en definitiva, persigue como finalidad primaria la conservación de los inmuebles existentes en el área territorial comprendida en la declaración de Conjunto Histórico, conservando así el sabor urbanístico tradicional de esa zona, y sólo autorizando la edificación sustitutoria o parte de ella, cuando precisamente no se pierda ese entramado cultural-urbanístico-ambiental.

Claro está que todos esos conceptos constituyen, por su propia naturaleza, conceptos jurídicos indeterminados, con frecuencia de no fácil plasmación y reconocimiento nítido.

En el supuesto aquí planteado, la sentencia recurrida, al valorar la prueba pericial, llega a la conclusión que el proyecto de obra, objeto de la licencia, tiene mayor altura, volumen y ocupación en planta, siendo expresivo, como en el supuesto de las alineaciones, del incumplimiento de las limitaciones impuestas por la LPHE... Procede, pues en virtud de lo expuesto, la desestimación del motivo". 
ra debido suponer la adaptación de éstas, en su caso a través de la redacción de plan especial o modificación en este caso de las Normas Subsidiarias, de conformidad con la literalidad del art. 36. 1 LPHIB. Y la omisión de tal obligación no supone que el Ayuntamiento sólo deba considerar tal planificación urbanística. En consecuencia el Tribunal no se limita a analizar el contraste de la licencia con las Normas Subsidiarias sino con la LPHIB. En este sentido el TSJ Illes Balears va a declarar primero que la autorización del Consell es firme (FD $4 .^{\circ}$ in fine), por lo que a esta no le afectará el fallo, pero estudia la legalidad de la licencia municipal, y ello porque, siguiendo la argumentación anterior, considera (FD 2. ${ }^{\circ}$, apdo. $7 .^{\circ}$ ) aplicable directamente al Ayuntamiento la prohibición de intervenir en el conjunto de conformidad con el art. 37. 2. ${ }^{\circ}$ LPHIB. De ahí que el Tribunal observe si se cumple en primer lugar la exigencia de que la sustitución contribuya a la conservación general del conjunto (del art. 39. 2 LPHIB, que cita en referencia al art. 41. 2 por error o conexión material, FD 2. ${ }^{\circ}$, apdo. $6 .^{\circ}$ ) y concluye que "no consta en modo alguno motivación técnica" que lo explique.

Seguidamente el Tribunal se pronuncia (FD 3..$^{\circ}$ ) sobre la interpretación del art. 37. 2 LPHIB (prohibición de modificar alineaciones, alterar la edificabilidad, o realizar agregaciones o parcelaciones, en conjuntos sin plan especial aprobado) al caso. Y lo más relevante al respecto va a ser la desestimación de la alegación del Ayuntamiento en el sentido de que la interpretación acerca de que tal inalterabilidad vendría referida a la edificabilidad prevista en las Normas Subsidiarias pero no a la existente. Y ello, esencialmente, porque, según el Tribunal esa misma cautela respecto a la edificabilidad está precisada para las alineaciones "existentes" en el art. 39. 3 PHIB (FD 3. ${ }^{\circ}, 3$ ), ya que en la medida en que no existe plan especial aprobado será necesaria, como también se ha expuesto supra, una interpretación restrictiva (FD 3..$^{\circ}$, apdos. $4 .^{\circ}, 5 .^{\circ}$ y $\left.6 .^{\circ}\right)$, y porque según ese criterio vendría referido a las alineaciones existentes en la STS 27-3-2007 con base en el art. 20. 3 LPHE (FD 3. ${ }^{\circ}$, apdo. $\left.7 .^{\circ}\right)$ y no a las previstas en el planeamiento urbanístico.

La necesidad de observar el caso desde la LPHIB y no sólo con base en las Normas Subsidiarias que no se habían adaptado a esa, no representa ninguna novedad de esta sentencia. Lo cierto es que dificilmente se podría justificar lo contrario, esto es que el planeamiento urbanístico, de naturaleza reglamentaria, pudiera en algún caso vulnerar lo establecido en una Ley (LPHIB o LPHE), por lo que es esta una premisa básica del ordenamiento jurídico, el principio de jerarquía normativa y la nulidad en cuyo incumplimiento deriva, como establece hoy el art. 62. 2 LRJ-PAC, o en argumentación paralela, tampoco sería admisible que un acto administrativo (licencia) vulnerara lo establecido en la LPHIB y 
permitiera adquirir derechos sin los requisitos legales o frente a prohibiciones expresas (art. 62. 1 LRJ-PAC). La vinculación al Ayuntamiento de las prescripciones de la LPHE y LPHIB es indiscutible, como recordó la STSJCyL, citada, 26-11-2004, en su FD 3. ${ }^{\circ}$, o como se derivaba de la declaración de nulidad de la licencia municipal de la STS 29-1-2002, citada, o expresamente de nuevo en la mencionada STS 4-10-2001 (FD 2. ${ }^{\circ}$ ), con base en la STS 23-11-2000.

\section{b) La modificación de entornos previa a plan especial}

En los entornos delimitados en la declaración regirá la exigencia de autorización como en el resto del conjunto (art. 20. 3 LPHE), sin que la regulación estatal precise otro régimen cautelar específico para los entornos, lo que sí puede haber sido objeto de regulación de las Comunidades. La ausencia de mayor precisión podría llevar a una interpretación precipitada: conforme a la LPHE sería igualmente posible la sustitución de inmuebles en tanto se respetaran las cautelas mencionadas, esto es, que no alteraran la edificabilidad ni las alineaciones, de forma paralela al régimen jurídico de los conjuntos. Prima facie, al igual que en el supuesto de los conjuntos, cabría interpretar que ante la ausencia de especificidad en el ámbito de los entornos, a estos se les deberían aplicar las prohibiciones generales que de forma cautelar se han establecido para los conjuntos, esto es, se debería respectar no sólo el régimen general (en los entornos, protección de la perspectiva visual del conjunto, infra) sino que además de forma más estricta se prohibiría la afección de las alineaciones y edificabilidad.

Efectivamente algunas Comunidades tampoco han detallado este supuesto $^{25}$ (salvo art. 33 LPHM que expresamente establece la misma protección pa-

Así en el art. 34.2 LPHCanar; en los arts. 41 y 42 LPHEx; arts. 46 y 47 LPHGa; o art. 28. 2 y 29. 1 LPCPV; el art. 37. 2 LPHIB, que no han excluido expresamente a los entornos de la regulación cautelar, en ausencia de plan especial. El art. 41 LPHIB regula las intervenciones tanto en conjuntos (apdo. 2 del art. 41) como en el entorno (art. 41. 3). Similar lectura se debe hacer de los arts. 42. 4 y 38 LPCGyL, que, respectivamente, han determinado la prohibición general y el régimen de intervenciones en conjuntos (apdo. 1 del art. 38) y del entorno (apdo. 2 del art. 38); o en los arts. 53. 1 y 43. 8 LPCHARio; o arts. 37. 2, 38, 39 y 40 LPCNa. La misma declaración genérica preceptúa el art. 46. 2 LPCAr, que si bien concreta la doble autorización para los entornos (arts. 35. 2 y 36.2 LPCAr, entre otros) no ha concretado en un precepto específico las intervenciones en entornos. Tampoco hay precisión respecto al entorno en los genéricos arts. 35. 2 y 39. 2 LPGVa, que como ya se ha comentado es más permisiva en general en el conjunto de forma previa a la aprobación del plan (como ya se ha señalado, de forma contraria al art. 20. 3 LPHE), ya que decide el Consell. La LPGMur sólo se refiere a los entornos de los monumentos (art. 42 entre otros), lo que puede llevar a pensar que no hay declaración de entornos o, por aplicación directa de los arts. 11.2 y 17 LPHE, seguirán el mismo régimen que los conjuntos. 
ra el entorno que para el $\mathrm{BIC}^{26}$ ), aunque en otras se ha concretado la prohibición para las zonas delimitadas como conjuntos pero no para sus entornos, donde será necesaria la autorización de la Comunidad en tanto se apruebe el plan pero sólo se controla si afecta a la contemplación del conjunto ${ }^{27}$.

En este sentido debe interpretarse la STSJ de C. Valenciana de fecha 4-11-2002 (rec. n 1660/2002), que anula la denegación por la comunidad autónoma de la autorización para la construcción de hotel y aparcamientos en zona al parecer de entorno de monumento histórico (presupongo que sin alterar edificabilidad o alineaciones), en primer lugar (FFDD 7. $.^{\circ}, 8 .^{\circ}, 12 .^{\circ}$ y $13 .^{\circ}$ ) al considerar que la Comunidad no puede en su autorización denegar meramente con base en el planeamiento urbanístico (ya que esta sería una competencia que sólo podría controlar el Ayuntamiento a través de la licencia municipal), y en segundo lugar, porque desestima la apreciación de que concurre la afección o impacto visual del monumento. A juicio del Tribunal, tal materia (que en este caso sí es objeto de competencia del órgano de protección del patrimonio cultural autonómico), no es de ejercicio discrecional como alegó la Comunidad, sino que son actos reglados que interpretan un concepto jurídico

El art. 17 LPHMa declara la misma protección para el entorno que para el BIC, si bien en los arts. 30 y 32. 2 se determina una gradación en la protección y en el segundo una protección del entorno en tanto impida la visualización o suponga alteración geomorfológica, en el mismo sentido que el art. 41. 3 LPHIB.

Parece que el origen de esta interpretación podría encontrarse en la LPCCat: no se especifica esta prohibición cautelar tampoco para los conjuntos y sólo se determina como prohibición general o criterio de intervención en los conjuntos (art. 35. 2 LPCGat) la alteración de alineaciones y edificabilidad salvo cuando mejore la conservación del conjunto, y en el art. 35 . 3 LPCCat respecto a los entornos, se establece su protección en cuanto afecte a la visualización o a su geomorfología. Es decir, en Cataluña, parece aplicarse el mismo régimen antes o después del plan especial, y con protección diferenciada para los conjuntos y sus entornos, en ambos supuestos, por lo que en los entornos ni en los conjuntos se aplica esta cautela, aunque en el caso de los conjuntos, como se ha dicho, resulta de aplicación directa la prohibición del art. 20. 3 LPHE. En regulación posterior de otras Comunidades, aunque sí establezcan la prohibición cautelar del art. 20. 3 LPHE de no afectar a alineaciones o edificabilidad en conjuntos sin plan especial, se excluye para los entornos: así el art. 56 LPCAst; el art. 52 LPCCant que determina las actuaciones anteriores (apdo. 1) y posteriores (apdo. 4) al plan especial, y en aquel caso previa autorización del Departamento de Cultura que determinará los criterios y condiciones de la intervención. 
indeterminado (FFDD $16 .^{\circ}$ a $32 .^{\circ}$ ), de cuya aplicación por la autorización de la Comunidad discrepa el Tribunal, y en consecuencia anula ${ }^{28}$.

Las determinaciones de las normas de protección cultural de Cantabria, Asturias y Murcia, sin embargo, sí resultan, a mi juicio, esclarecedoras, no sólo para estas Comunidades, sino para integrar adecuadamente el silencio le$\mathrm{gal}^{29}$ : posiblemente, en ausencia de mayor precisión, no tiene por qué deducirse que en los entornos se aplique sin más la prohibición provisional de afectar a la edificabilidad o alineaciones de los conjuntos sin plan especial. Tal cautela, según mi criterio, es sólo una determinación específica para las zonas delimitadas como conjunto. Carece de sentido su extensión a las zonas delimitadas como entorno para las que no exista a priori una protección de su estructura si no afecta a la contemplación del conjunto o alteración grave de la geomorfología de la zona ${ }^{30}$ que sea causa de su declaración. Sólo en el art. 33 LPHM hay una extensión de la prohibición cautelar respecto a los entornos, por lo que evidentemente se estará a lo establecido expresamente en este precepto, que excluye mayor interpretación. Esta medida provisional de la legislación de la Comunidad de Madrid que impide la modificación de alineaciones, rasantes, parcelaciones o edificabilidad, se recuerda en la STS 18-12-2002, citada, que conoció del recurso frente al proyecto de ampliación del Museo del Prado en el atrio de los Jerónimos. El Tribunal, de forma muy discutible, considera que el Acuerdo del Consejo de Ministros de 2-10-1998 (competente en cuanto se trataba de monumento de titularidad estatal, dada su gestión por la Administración del Estado en virtud de convenio celebrado entre el Ministerio de Educación y Cultura y la Archidiócesis de Madrid), no vulnera tal limitación ya que el mismo "ordena la iniciación del procedimiento de revisión del planeamiento" (FD. $\left.11^{\circ}\right)$, lo que determinaría, a juicio del Tribunal, el cumplimiento de la Ley, pues "es suficiente aprobar los instrumentos de planeamiento urbanístico que

$\mathrm{El}$ art. 39. 3 LPCVa establece en concreto las determinaciones del plan especial para el entorno de monumentos.

No se trata de hacer una interpretación de la norma estatal conforme a la regulación de las Comunidades aplicable a las que carecen de mayor precisión, sino de utilizar la argumentación lógica que el legislador de las Comunidades de Cantabria, Asturias y Murcia ha determinado en el marco del art. 20. 3 LPHE.

Como concretan los arts. 35. 3 LPCCat, 32.2 LPHMa; 41. 3 LPHIB. Véase la STSJ de Galicia de 20-2-2004, que se cita en el apdo. siguiente sobre actuaciones en entorno sin plan especial aprobado. 
desarrollen el régimen de protección para enervar la prohibición que contiene el expresado artículo 33". El problema del caso expuesto, a mi juicio, es que se trata de un Acuerdo aprobado antes del planeamiento especial, que para no vulnerar frontalmente la prohibición cautelar -sin plan especial- de obras sin respetar alineaciones, rasantes, parcelación o edificabilidad, excluyó la aprobación de proyecto técnico, lo que probablemente se explica porque era el Estado el titular del patrimonio cultural, pero sin competencias urbanísticas, y probablemente sin que el Ayuntamiento o la Comunidad participaran en el citado convenio, y de ahí, además, la perplejidad que reflejan los dos votos particulares en la Sentencia, que consideran nulo el Acuerdo al carecer de proyecto técnico que detalle las obras. Esta extraña situación se debió abordar mediante convenio entre todas las Administraciones y la Archidiócesis, para que el Ayuntamiento y la Comunidad elaboraran la reforma del plan especial antes de que en su caso el Gobierno aprobara el Acuerdo con el proyecto técnico incluido. Sólo entonces se habría tratado de un proyecto acorde con el art. 33 de la Ley 10/1998 LPHCM. Tal como se sucedieron las actuaciones administrativas, el Acuerdo debió ser considerado, según mi criterio, contrario al art. 33 LPHCM.

\section{c) Exigencia de doble autorización en el conjunto y su entorno: con- currencia de la competencia municipal y de la comunidad autóno- ma (o isla)}

En ausencia de plan especial no hay duda de que la competencia urbanística local concurre con la de patrimonio histórico de la comunidad autónoma o isla, tanto para los conjuntos como sus entornos, como se deriva del art. 20 $\mathrm{LPHE}^{31}$ y se establece en la legislación de las comunidades autónomas ${ }^{32}$, sal-

Una crítica a esta previsión porque supondría una desconfianza en la administración local, en F. MORA BONGERA, "La protección de los conjuntos históricos a través del planeamiento. El caso específico de Santa María del Campo de Viveiro", Revista de Derecho Urbanístico, no 116 , 1990 , pp. 47-65, en concreto p. 63, con base en la autonomía local.

Así como ejemplo, art. 34. 2 LPCCat; art. 37. 2 LPHIB, competencia del Consell Insular; art. 46. 1 LPGAr; art. 56 PCAst; art. 64. 1 LPCGant; art. 44. 1 LPCGyL; art. 53. 1 LPGHARio; art. 46. 1 LPCMur, que lo excluye en su apdo. $2^{\circ}$ para el interior de los inmuebles; art. 37.2 LPCNa; art. 33. 1 LPHCanar a favor del Cabildo Insular; art. 42. 1 LPCEx; art. 33. 3 para los bienes del catálogo - art. 25- en relación con el art. 40 LPHAnd; art. 47. 2 LPHGa. En la LPHC-LM, parece un defecto de regulación la ausencia de mención de la autorización de la Comunidad, pues en los arts. 13.1 (en general) y 14 (derribo) parecen partir de la exigencia de autorización de la Comunidad. 
vo en la LPHM, que si no es laguna legal, parece prescindir de la autorización de la Comunidad sea en conjuntos o entornos ${ }^{33}$.

En este sentido los pronunciamientos de la STSJ de Extremadura de 27-9-2000 (rec. $\mathrm{n}^{\circ}$ 509/1997), sobre construcción de una vivienda en una zona declarada conjunto, y en los mismos términos para el supuesto de edificios situados en el entorno de un conjunto, la STSJ de Galicia de 20-2-2004 (rec. $\mathrm{n}^{\circ}$ 4354/2000), que en su FD 3. ${ }^{\circ}$ resuelve confirmando la resolución autonómica que deniega la legalización de una terraza construida en el entorno ${ }^{34}$. Se puede

El art. 32, en sus apdos. 1 y 2, LPHMa establece exclusivamente la autorización municipal (toda vez que, si no es una laguna, puede haberla considerado innecesaria el legislador al imponer la prohibición general de afectar a alineaciones y edificabilidad en el art. 33 LPHMa, ex ante, esto es, sin plan especial), así con carácter general, salvo en los supuestos de demolición (art. 26 LPHMa). El resultado es bastante insatisfactorio técnicamente: se parte en el art. 8. 3 LPHMa de la autorización de la Comunidad en todo caso para cualquier bien del patrimonio cultural; de otro lado parece que el art. 32 LPHMa la excluye en estos supuestos de obras en conjuntos aunque no cuenten con plan especial; y finalmente en los supuestos de demoliciones se vuelve a exigir en su art. 26, dejando, a su vez, una laguna para el supuesto de demoliciones con plan especial aprobado (vid. infra).

"La terraza construida por el demandante se encuentra dentro del entorno del conjunto histórico-artístico... Por ello... como señala el TS en su sentencia de 21 de noviembre de 2000 ( RJ 2000, 10267) en la que se dice «... recordar los razonamientos que este Tribunal Supremo aceptó en su sentencia de 23 de julio de 1992, dictada en el recurso de apelación número 8230 de 1990 ( RJ 1992, 6173)... no puede olvidarse que en materia del Patrimonio Histórico-artístico, incluso con arreglo a la vieja normativa, se da un supuesto de competencias concurrentes; de una parte, la competencia municipal que interviene en aras de lograr que las construcciones y edificaciones se sometan a la legalidad urbanística, y de otra, la competencia estatal o autonómica, que persigue el ajuste de las obras al interés cultural, histórico y artístico; concurrencia que no supone interferencias, pues cada orden competencial ha de resolver el supuesto de acuerdo con la normativa que le es aplicable... la vía municipal y autonómica, como se ha dicho, son independientes desarrollando cada una su vida propia, tanto a los efectos procedimentales, como a los posibles efectos impugnatorios de los actos que en una y otra pudieran dictarse...»; por lo que la alegación del demandante referente a la posible legalización de la construcción con arreglo a los parámetros urbanísticos establecidos en el Estudio de Detalle, ha de ser desestimada, puesto que aquí no está en cuestión la normativa urbanística sino la de protección del patrimonio cultural y la evitación de actuaciones por particulares que puedan afectar a los valores propios del mismo o su contemplación, apreciación o estudio, debiendo cuidar la administración autonómica que el volumen, tipología, morfología y cromatismo de las intervenciones en el entorno de los monumentos no puedan alterar el carácter arquitectónico y paisajístico de la zona, ni perturbar la contemplación del bien (art. 44 de la Ley 8/95) por lo que ha de concluirse que señalado por los informes técnicos que la construcción distorsiona gravemente el conjunto, tanto 
citar también la STSJ de Andalucía de fecha 26-12-2001 (rec. nº 54/2000). De esta forma, las obras en conjunto histórico o su entorno sin la autorización del órgano competente en materia de patrimonio histórico, serán sancionables, como confirma la STSJ de Andalucía de 26-12-2001 (rec. nº 54/2000), en otro peculiar caso en el que el sujeto infractor es además el propio Ayuntamiento (Montefrío, Granada), previendo además para otros casos diferentes al enjuiciado, que tal obligación de obtener autorización lo será, como recordaba la STS 2-2-2000 citada, hasta que se apruebe el plan especial.

Se plantean dudas, sin embargo, acerca de la autorización requerida para las sustituciones de inmuebles, si es para intervenciones en cualquier bien situado en el conjunto o entorno sin plan especial, aun cuando el inmueble en concreto no haya sido objeto de declaración especial o singular. A mi juicio, cualquier sustitución en conjunto o su entorno sin plan especial requerirá la autorización de la Comunidad (o Isla) se trate del inmueble que sea, ya que a priori, sin el plan especial ni los estudios que le preceden, no pueden excluirse valores culturales en algunos de los inmuebles.

Parece, sin embargo que esto se ha discutido en un pronunciamiento del Tribunal Supremo, STS 23-10-1995 (rec. no 279/1992) -aunque no está suficientemente claro si hay o no plan especial aprobado- que confirma la nulidad parcial de la resolución de la comunidad autónoma en cuanto imponía la obligación de conservar fachadas de edificio declarado en ruina por el Ayuntamiento de Murcia, al considerar que, si bien estaba enclavado en conjunto histórico, sin embargo no contaba con declaración singular de interés cultural, por lo que, a su juicio, no le resultaba de aplicación la obligación de conservación de los bienes BIC. Aparentemente es una demolición de inmueble en conjunto histórico sin plan especial, y la comunidad autónoma impone la obligación de conservar la fachada y la reposición del edificio de acuerdo con las directrices que ordene la propia Comunidad. El Tribunal Supremo confirma la nulidad de la obligación de conservar la fachada y confirma la de reposición, porque, según afirma el Tribunal de instancia, aunque no se trate de BIC sí tendría protección ambiental, y esta calificación ambiental ya no la puede discutir el Tribunal Supremo ${ }^{35}$. En esta STS 23-10-1995 se podría

por su preponderancia como por los materiales empleados, resultando irrelevante la separación de la terraza del conjunto por una rampa de salida al río, porque tal circunstancia ni excluye su afectación por el área de protección de 100 metros establecida en la Resolución de la Consellería de Ordenación del Territorio de 14 de mayo de 1991 ni evita la distorsión del entorno por sus características constructivas. "

El pronunciamiento es bastante sorprendente sin duda porque deben faltar datos relevantes para su lectura, y además discute si se trata o no de BIC por razón de derecho transitorio, en argumentación que merece su transcripción aunque sea prolija: 
apuntar la idea de que no en todo el conjunto se aplicarían las obligaciones de conservar, lo que a mi juicio no es asumible en ausencia de plan especial. Confunde la alusión al art. 21. 3 LPHE, que debería aplicarse sólo cuando existe plan especial. Si fuera ese el caso, con plan especial, estaría clara la nulidad (total y no sólo parcial, como acuerda el Tribunal) de la autorización de la Comunidad, porque tratándose de un conjunto, si no hay una declaración singular de monumento o jardín históricos, zona arqueológica o paleontológica, tal autorización está expresamente excluida en el art. 20. 4 LPHE (en relación con el art. 22. 1 LPHE, para las zonas arqueológicas y paleontológicas). En ese supuesto el pronunciamiento del Tribunal debiera haber estimado la nulidad de la autorización por la incompetencia de la comunidad autónoma sin que resulte asimilable a las categorías de zonas arqueológicas o paleontológicas o monumentos y jardines, de los arts. 20. 4 y 22.1 LPHE. Ahora bien, si no hay plan especial, no tiene base legal el argumento genérico del Tribunal (sin declaración singular no habría protección por la LPHE), ya que sin plan hay que aplicar la regla gene-

“... 3. ${ }^{\text {a }}$ En el caso que resolvemos, el bien inmueble sito en la calle Alfaro número 8 de Murcia, está comprendido dentro del sector declarado conjunto histórico por Decreto 423/1976, de 6 febrero, y se trata de un bien declarado en estado de ruina por el Consejo de la Gerencia de Urbanismo de Murcia y no aparece ni inventariado ni catalogado, al amparo de la legislación

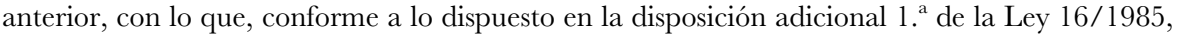
no pasó a tener la consideración de «bien de interés cultural». Por ello, para que pueda gozar de la protección singular de la citada Ley, sería necesario que de forma individualizada (art. 9.1 Ley 16/1985), se declarara bien de interés cultural; y como esto no consta ni en el expediente ni en el proceso seguido en la instancia, es por lo que la sentencia recurrida, declaró que el citado bien no es un bien de interés cultural. El concepto de bien cultural, es un concepto jurídico indeterminado, cuyo contenido debe llenarse a través del expediente de declaración de bien de interés cultural, lo que no consta en el caso que nos ocupa.

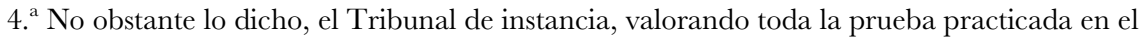
expediente y en el proceso, llegó a la convicción - lo que no es cuestionable en casación- de que el bien a que nos referimos es un bien de características ambientales. Tal convicción obligó al Tribunal «a quo» a aplicar el artículo 21.3 de la Ley de Patrimonio Histórico Español, y por ello estimó en parte el recurso contencioso-administrativo interpuesto por doña María Luisa G. A., contra la Orden de la Consejería de Cultura, Educación y Turismo de la Comunidad Autónoma de la Región de Murcia, de fecha 21 enero 1991, que anuló y dejó sin efecto únicamente en cuanto imponía la obligación de conservar las fachadas del edificio referido, cuya demolición se autoriza condicionada a su reposición, con las garantías de que la reposición del nuevo edificio que se levante lo sea ajustándose la propietaria del mismo a las directrices que establezca la Administración, para que se lleve a cabo la reposición del edificio con absoluta fidelidad, dado que se trata de un bien de características ambientales dentro del Conjunto Histórico en el que está ubicado; de esta manera la propiedad privada sirve al interés público, con respeto al interés privado." (FD 3. ${ }^{\circ}$, cursiva en negrita en original). 
ral de intervención de la Comunidad (en virtud del art. 20. 3 y reiterado en los supuestos de ruina, si fuera el caso, en el art. 24. 2 LPHE), con independencia de los valores que concurran o aparente a priori (aún sin el plan puede ser dificil advertirlo) en el bien que forma parte de ese conjunto histórico.

\section{d) La solución de discrepancias entre las dos Administraciones competentes}

Alguna discusión ha suscitado la articulación entre las competencias en materia de protección del patrimonio cultural y las urbanísticas en caso de discrepancias entre el informe o autorización de la Comunidad (o isla) y la licencia urbanística. En esos casos se atenderá a la prevalencia que otorga la legislación al requerir informe favorable (obstativo) del órgano competente en protección de patrimonio (art. 20. 3 LPHE expresamente) ${ }^{36}$, siempre que la motivación de la Comunidad se inserte en el ámbito de sus competencias culturales, esto es, que no pretenda un mero control urbanístico (de la planificación urbana) de las intervenciones, que sólo corresponde al Ayuntamiento (como se resuelve en la STSJ de C. Valenciana de 4-11-2004 que se comentará infra).

La prevalencia de las competencias culturales sobre las urbanísticas (y no sólo de la evidente preferencia de la ley, LPH o LPC, sobre los reglamentos, planeamiento urbanístico), sí es apreciable y ya fue señalada por diversas sentencias de conformidad con la Ley de 13 de mayo de $1933^{37}$ de protección del patrimonio histórico-artístico, anteriores por tanto a la previsión actual de la LPHE, que hoy se debe tener en cuenta en estos supuestos de intervenciones en conjuntos sin plan especial aprobado o en general donde subsista la necesidad de doble autorización. Se partía de la predicada concurrencia de competencias para la declaración de ruina en conjuntos (STS 9-2-1988, RJ 870, y STS 19-7-1999, RJ 6315). Así en la STS 19-11-1991 (rec. nº 2224/1989), en su

Art. 29. 4 LPHAnd; art. 45. 1 LPHGa; art. 40. 1 LPHEx; el art. 36. 2 LPHIB; art. 34.2 LPCVa, que lo califica como vinculante, lo que tendrá los mismos efectos, el informe es obstativo en todo caso.

Sobre la regulación anterior vid. P. BENSUSÁN MARTÍN: La protección urbanística de los bienes inmuebles históricos, 1996, pp. 58 ss; y M. ALMAGRO-GORBEA, "La protección del patrimonio cultural en la historia de España", en La protección jurídica del patrimonio inmobiliario histórico, 2005, dir. Martín Almagro-Gorbea/Antonio Pau, pp. 17-34. 
FD 2. ${ }^{\circ}$ reconoce el mayor valor de las competencias culturales del art. 45 de la Constitución ${ }^{38}$. Esta Sentencia tiene claros y numerosos precedentes judiciales, como de forma precisa detalla la STS 3-10-1986 (RJ 5287) con cita de varias sentencias del Tribunal Supremo de fechas comprendidas entre 1966 y 1984, Sentencia que confirma la resolución del entonces competente Ministerio de Cultura que denegaba la sustitución de inmueble en conjunto histórico de Sevilla a pesar de que hubiese una posición favorable del Ayuntamiento. En su FD 5. ${ }^{\circ}$ esta Sentencia recoge además la jurisprudencia que enmarcó y limitó esta prevalencia en el respeto a los actos previos del órgano de protección del patrimonio $^{39}$.

FD 5. $.^{\circ}:$ “... en esta materia son concurrentes y no excluyentes entre sí las competencias de los Ayuntamientos, para la concesión de licencias de obras... en relación con las obras que pretendan modificar edificios inmediatos a un Monumento Histórico-Artístico, y las de nueva construcción en igual emplazamiento, o que alteren el paisaje que lo rodea o su ambiente propio,... ello no obstante, las licencias de obras concedidas por los Ayuntamientos no pueden tener más alcance que el que deriva de su propia naturaleza y ámbito urbanístico, estando siempre supeditadas en estos supuestos especiales a la decisión favorable de los órganos encargados de la protección de dicho Patrimonio, porque sus competencias son prevalentes respecto de las que tiene el Municipio en caso de conflicto, al estar dirigidas las primeras a la defensa del derecho social a la cultura y el interés público superior, reconocidos en el art. 45 de la Constitución".

FD 1.: "Naturalmente, toda potestad tiene límites, como resulta de los artículos 9 y 103 de la Constitución. La jurisprudencia citada en el fundamento de derecho anterior es consciente de ello, y de que la potestad discrecional a que se refiere no es absoluta, de modo que pueda redundar en arbitrariedad, sino que ha de ejercitarse en términos razonables; y por eso, algunas de las Sentencias citadas han dejado sin efecto órdenes de demolición, dictadas por los órganos del Patrimonio Histórico-Artístico, porque los terrenos en que estaban aquéllas habían pasado a ser vía pública, sobre la que los dueños del inmueble no tenían ya dominio ni podían edificar, aparte de que la Comisión Provincial había informado que retranquear la fachada no producía daño o perjuicio irreparable al conjunto histórico-artístico de la zona -Sentencia de siete de Junio de mil novecientos ochenta y dos (RJ 1982\4200)-, o porque el edificio había sido declarado en estado de ruina inminente, y su conservación implicaba un grave riesgo para personas y cosas, por lo que el Ayuntamiento impuso el derribo -Sentencias de veintitrés de Junio de mil novecientos ochenta y dos (RJ 1982\7312), veintitrés de Abril de mil novecientos ochenta y tres (RJ 1983\6039), siete de Mayo y diez de Noviembre de mil novecientos ochenta y cuatro (RJ 1984\2857 y RJ 1984\5526)-; o deja sin efecto una Orden de la Dirección General de Bellas Artes que ordenaba reducir a dos plantas de la nueva edificación porque la misma Dirección General había informado favorablemente un Plan Parcial que permitía tres alturas, y este informe vinculaba a dicha Dirección General, puesto que era ella el órgano competente para emitir tal informe y, por tanto, no podía ir contra sus propios actos".

Para terminar concluyendo (FD 6..$^{\circ}$ que en el caso estudiado no existía ningún acto previo que pueda vincular a la Dirección General a autorizar las alturas pretendidas por el recurrente. 
La prevalencia de la competencia cultural de la comunidad autónoma sobre la urbanística municipal también se ha afirmado en la posterior STSJ de Castilla y León 7-10-2003 (rec. n ${ }^{\circ}$ 2591/1998) ante la impugnación por el Ayuntamiento de Carucedo (León) del Decreto de la Comunidad que declaró la zona arqueológica de Las Médulas. Esta Sentencia, con base en la anterior Sentencia de esa Sala de 29-2-1996 - exigencia de doble autorización también en el entorno de conjuntos mientras no haya plan especial aprobado-, resuelve en su FD 1. ${ }^{\circ}$ la ausencia de afección a la autonomía local por la aprobación de zona arqueológica y la subsiguiente exigencia de autorización de la comunidad autónoma por la protección del patrimonio cultural ${ }^{40}$.

La referida inexistencia de competencia autonómica urbanística en el control que ejerza a través de la autorización en intervenciones en conjuntos sin plan especial, no tiene, sin embargo, un reverso equiparable que impida al Ayuntamiento controlar en función de una competencia general de protección cultural, teniendo en cuenta que éste puede aplicar otras previsiones, también en defensa del patrimonio, que haya adicionado el planeamiento, o que, como se ha visto, se trate de normas de aplicación directa, que también debe tener en cuenta el propio Ayuntamiento. En este sentido además de las sentencias citadas, se puede hacer referencia a la STSJ de Aragón de fecha 2-3-2001 (rec.

"En el ejercicio de las respectivas competencias es posible que surjan puntos de fricción y para ello la jurisprudencia ( Sentencias Tribunal Supremo de 30 de octubre de 1986, 8 de mayo de 1987, 12 de marzo y 6 de abril de 1992 ha dicho que debe ser interpretada la normativa legal en el sentido más favorable a la conservación del patrimonio; por ello los organismos protectores pueden, separándose incluso, si ello fuera necesario, de las normas urbanísticas y de las licencias que hubieren otorgado otros organismos, adoptar e imponer limitaciones que discrecionalmente estimen necesario para tal fin.

Siendo así las cosas, cabe afirmar que, con independencia del planeamiento urbanístico para un conjunto histórico-artístico, la Comunidad Autónoma, en este caso la Junta de Castilla y León, por las competencias transferidas, tiene y puede ejercer las atribuciones que la Ley 16/85 le concede en materia de patrimonio histórico-artístico. Y si en el ejercicio de aquellas hay fricción con las municipales, deberán prevalecer las que consigan mejor el objetivo de conservar aquel patrimonio.

Y en el caso de autos, las declaraciones de entornos de unos bienes de interés cultural permiten ampliar e intensificar aquel objetivo, razón que conduce a dar prioridad a los actos emanados por la Administración Autonómica».

...

"Como se ve no hay vaciamiento de la autonomía local o de las competencias municipales sobre el suelo, sino una concurrencia de éstas con atribuciones superiores y autonómicas relativas al patrimonio histórico-artístico. Entonces aquellas disposiciones normativas denunciadas como infringidas no han sido contravenidas." 
$\left.\mathrm{n}^{\circ} 1164 / 1997\right)$, que confirma la resolución municipal que, con base en el planeamiento general, impuso la obligación de conservación in situ de elementos muebles y decorativos (marquetería y fachada de una joyería) de un inmueble con expediente BIC incoado ${ }^{41}$.

\section{e) Motivación de las resoluciones del municipio y de la comunidad autónoma o isla}

También la STS 18-12-1997 (rec. n 3068/1992), ante una alegación sobre la incompetencia municipal, refiere cómo las competencias urbanísticas incluyen la protección de edificios o conjuntos, y a su vez requiere una suficiente motivación, en un caso con errático procedimiento en el que se suceden informes favorables y desfavorables de ambas administraciones ${ }^{42}$. La motivación es

"... Así las cosas, es claro que el Ayuntamiento demandado obró dentro de su función competencial, que le era atribuida cuando dispuso, que los elementos que conformaban el mobiliario y la decoración (entendiéndose incluida la marquesina y fachada de la joyería Aladrén) permanecerán "in situ" puesto que estos elementos, tal y como se deduce del informe pericial practicado en las actuaciones, que goza de las garantías de imparcialidad y eficacia para el esclarecimiento de los hechos, que conforman los elementos decorativos, no podrían arrancarse, sin causar menoscabo en las paredes y techos del inmueble. Por lo que el Ayuntamiento no se extralimitó en su cometido cuando determinó que debían permanecer "in situ" y cualquier actuación que se llevara sobre los mismos contara con el permiso municipal e informe favorable de la Comisión del Patrimonio Histórico Artístico, pues tal y como dispone el art. 8.1.3 del PGOU de Zaragoza previamente a la realización de cualquier tipo de obras será necesario realizar un levantamiento gráfico de la totalidad del edificio y la intervención en este se realizará mediante un proyecto en el que además de las obras a realizar se analice y resuelva la relación de estas con el conjunto, tanto para la restauración de los elementos individualizados como para el resto, sin que en ningún caso se alteren los aspectos fundamentales del edificio...” (FD 3. ${ }^{\circ}$ ).

"Independientemente de la incorrecta contraposición entre razones históricas y urbanísticas, puesto que el urbanismo comprende con toda naturalidad la protección de los edificios o conjuntos cuyo valor histórico haga merecedores de conservación, en el supuesto presente no existe dato alguno que permita concluir que la solicitud de licencia presentada por el recurrente ponga en riesgo esos valores, ni la actuación de la Administración demandada ha plasmado en sus resoluciones denegatorias una motivación congruente con la decisión adoptada... Por todo lo cual procede estimar el presente recurso de apelación y reconocer el derecho del apelante a la obtención de la licencia de obras solicitada" (FD 5. ${ }^{\circ}$ ).

Y aunque en este caso no está aclarado en la Sentencia si ya estaba aprobado o en tramitación el plan especial de protección del conjunto, sí hay que destacar cómo la competencia de cultura en el supuesto de que esté aprobado el plan especial (como se detalla en el epígrafe siguiente III de este trabajo), ya corresponde a la entidad municipal, según declara el Tribunal Supremo FD 3. ${ }^{\circ}$ STS 18-12-1997, citada. 
exigible no sólo a la licencia municipal sino también a la autorización autonómica (o insular en su caso) en estos supuestos previos a la aprobación de plan especial de protección del conjunto. Con este fundamento la STSJ de Galicia de 25-2-2004 (rec. $\left.\mathrm{n}^{\circ} 715 / 2001\right)$ anula la resolución de la comunidad autónoma que autoriza edificar nueva planta. En este caso también había habido cambios de criterios de la resolución supuestamente porque las obras denegadas afectarían a la armonía del conjunto y supondrían alteración de volúmenes. El Tribunal requiere la motivación ${ }^{43}$ y ordena la demolición una vez que evidencia cambios o alteración de volumen aun en el supuesto de que no existiera incremento de volumen, de acuerdo con una específica referencia de la regulación gallega ${ }^{44}$.

"Así pues, cabe deducir ahora que, como señala la demandada, se ha producido un cambio de criterio en la resolución recurrida; cambio que no consta razonado; lo cual era obviamente necesario máxime si la base para dictar tal resolución se dice que lo fue el informe-propuesta de la Comisión territorial de Patrimonio histórico en Pontevedra en reunión de 21 de noviembre de 2000; acta de la cual fue traída certificación a los autos en periodo de prueba a instancia del actor y nada se observa en su contenido que se refiera a la obra de litis en los particulares referentes a la ciudad de Tui; y aunque existe, ciertamente, un informe favorable del Arquitecto de la Consellería de Cultura, lo cierto es que no se refiere a él la resolución recurrida; aparte de que tampoco se razona en él por qué la obra sería ahora autorizable, cuando no lo era la anteriormente propuesta y de menor envergadura; así pues, sin conocer el por qué de todo este devenir, la resolución objeto del presente no es aceptable, porque se aparta de la pormenorización que tanto en lo fáctico, como en lo normativo exige cualquier autorización en un Conjunto histórico; pues, esa es la única forma de poder saber que se dan (y en concreto en este caso) los presupuestos de hecho justificantes de la potestad administrativa otorgada por la norma y ejercida en el supuesto de autos con resultado favorable para una persona, mas sin garantía de que haya sido cubierto también el interés general implicado en él; no basta, pues, con referencias tan genéricas como la de "responder al volumen preexistente y ser respetuosas con la edificación; contenidas en la resolución recurrida; por todo lo cual, la situación en el caso ya comportaría, cuando menos, una falta de motivación en los términos del artículo 54,1, a) de la ley de procedimiento administrativo común; vicio de forma que al producir obviamente indefensión en los afectados, se habría de traducir (artículo 63,2 de la misma ley) en una anulación de la resolución así dictada." (CDO. 1. ${ }^{\circ}$ ).

“... que a todo ello no empece el que la segunda de las plantas del edificio de litis (según se desprende de la abundante documental acompañada por la parte codemandada) ya llevase muchos años construida; pues, los apuntados indicios evidentes de que la misma desentonaba con las edificaciones aledañas inmediatas (observación que se desprende de los planos obrantes en autos) hacía precisa una cuidada justificación por parte de la Administración de Patrimonio cultural de que se podían autorizar unas obras que, como las del caso, vienen a consagrar en realidad esa desarmonía para otro importante periodo futuro; y, por eso mismo, tampoco desvirtúa lo expuesto, lo informado por la Perito-testigo propuesta por la parte codemandada en los 


\section{REMODELACIONES GON RESPETO A LA ESTRUCTURA URBANA ESTABLECIDAS EN PLANES ESPEGIALES DE PROTECGIÓN}

\section{a) Contenido general y límites de los planes especiales: la modifi- cación de alineaciones}

Se va a considerar en qué términos es factible la modificación de alineaciones y sustitución de inmuebles que pueda prever un plan especial de protección que afecte a zona del conjunto o a su entorno.

Como punto de partida, respecto al contenido de los planes especiales en general, se debe recordar que tienen una relación de especialidad y no de jerarquía respecto a los planes generales y con tal base se aprecia que la previsión de nuevas alineaciones y volúmenes es contenido propio de los planes especiales que podrán determinarlos con independencia de su determinación o no en los planes generales o normas subsidiarias (supletoriamente, art. 83.3 Reglamento de Planeamiento Urbanístico, aprobado por RD 2159/1978, en adelante RPU: previsiones en el plan especial que no consten en el planeamiento general), en tanto no se trate de modificaciones de la estructura general y orgánica de los planes generales. Se recordará que la distinción entre determinaciones generales o fundamentales se precisa en los arts. 19.1 B, y 25. 1 RPU, frente a las determinaciones pormenorizadas del art. 29.1 RPU, entre las que se encontrarían las alineaciones, volúmenes y alturas, como confirma la STSJ de Cataluña de 28-6-2002 (rec. nº 1939/1998).

autos, sobre que lo nuevamente construido no aumentaba sensiblemente el volumen; pues si, como va dicho, lo anteriormente existente ya desentonaba en relación con las edificaciones próximas, se aumentase o no el volumen (extremo al que se refiere el artículo 47 de la ley gallega 8 de 30 de octubre de 1995 ) la resolución recurrida debía justificar por qué se autoriza una edificación perturbadora de un conjunto; mas, a mayores de ello, y como va expuesto antes, la Arquitecto de la Consellería que giró visita en 22 de junio de 2000, a las obras de autos, entonces en curso, apreció que se producía alteración de alturas y cubierta con ellas; consiguientemente, se incidía igualmente en el supuesto del citado artículo 47 de la ley de patrimonio cultural de Galicia en el particular de las alteraciones del volumen, pues ello equivale a "cambios", provoquen o no un aumento final de ese volumen; y, desde luego, el cambio con la obra del caso era afectante, como va expuesto, a la armonía del conjunto en que se encuadra que es otro de los supuestos previstos en dicho artículo; y no porque ya fuese distorsionante lo existente, ha de permanecer en las obras futuras; pues fue para evitarlo, por lo que obviamente se dictó ese precepto; por todo lo cual, el recurso debe prosperar." (Cdo. 2. ${ }^{\circ}$ ). 
Más específica resulta la mencionada STS 8-4-1989 ${ }^{45}$ sobre la aprobación definitiva del Plan Especial de Protección del Casco Antiguo de Carlet, con una modificación de las alineaciones de una calle proyectadas en planeamiento general. En primer término, el Tribunal aprecia cómo el único límite a los planes especiales está en la estructura fundamental y orgánica del territorio. Y seguidamente, en concreto respecto a los planes especiales de protección del patrimonio histórico, el Tribunal aprecia de un lado qué es contenido propio de los planes especiales de protección, y, de otro, que en ese ámbito de competencia, el planificador puede decidir mantener viejas alineaciones ${ }^{46}$.

Un supuesto y pronunciamiento similar se expone en la STS 12-5-1992 (rec. $\mathrm{n}^{\circ}$ 1674/1988) que conoce el recurso frente al Acuerdo del Ayuntamiento de Valencia de aprobación definitiva del Plan Especial de Protección y Reforma Interior del Barrio del Carmen que mantenía lo que a juicio del demandante eran "estrechas y viejas calles medievales". El Tribunal con base en la doctrina jurisprudencial sobre la discrecionalidad resuelve que la decisión de

Sin $n^{\circ}$ de rec., RJ 3452.

FD 3. : "Los Planes Especiales de Protección del patrimonio histórico y artístico ordenan los aspectos de una realidad existente para evitar su destrucción y más concretamente la ordenación puede perfectamente hacer objeto de sus previsiones «las calles»-arts. 18, 1, b) del Texto Refundido y 78, 1, b) del Reglamento de Planeamiento.

$\Upsilon$ dado que las calles quedan definidas por varios elementos uno de los cuales, y fundamental, es el de las alineaciones, hay que entender que éstas pueden ser objeto de la ordenación propia de un Plan Especial de Protección.

En el supuesto litigioso, el Plan Especial impugnado pretende en lo que ahora importa mantener las alineaciones actualmente existentes en la realidad en un pequeño tramo de la calle San Francisco - hoy Sigró- en su confluencia con el Carrer Llarg para conservar la realidad existente tal como la ha trazado la historia y si con esta finalidad modifica las alineaciones dibujadas en ordenaciones anteriores ha de entenderse que esto resulta perfectamente lícito para un Plan de Protección: se trata de conservar un trazado real y actual producto del tiempo aunque para ello sea necesario modificar alineaciones meramente pretendidas o proyectadas, existentes en previsiones anteriores y cuya alteración no puede en modo alguno calificarse de modificación de la estructura general y orgánica.

Desde otro punto de vista es perfectamente viable que un Plan Especial como el litigioso de Conservación del Casco Antiguo mantenga viejas alineaciones, aun sin ser funcionales, pues el interés público atendido es precisamente el de la conservación. El propio documento aportado por la parte actora en su escrito de proposición de prueba subraya que «las edificaciones existentes» en la calle litigiosa «datan de antiguo» y que el Plan Especial impugnado «mantiene» el trazado «de la edificación existente». Y recuérdese que la conservación del patrimonio histórico es justamente uno de los cometidos que nuestra Constitución atribuye a los poderes públicos - art. 46-." (cursiva en negrita en original). 
mantener las alineaciones en el plan especial, forma parte de la discrecionalidad del planeamiento, que se controlará por los tribunales en primer lugar observando los hechos y en segundo término valorando la adecuación lógica de la solución adoptada en el plan con esos hechos dados (FD 3. ${ }^{\circ}$ ), lo que le lleva al Tribunal a considerar que no existe irracionalidad en el plan litigioso (FD $\left.4 .^{\circ}\right)^{47}$.

En el análisis de lo que constituya estructura fundamental del plan general a propósito de los límites de los planes especiales de reforma interior (art. 26 TRLS 1976), la STS de 8-5-198948 se pronuncia en términos muy reveladores sobre un plan especial de reforma interior del Velluters o del Pilar en Valencia, en el ámbito del "sector histórico-artístico" de un plan parcial, y confirma la modificación de alineaciones (apertura de nuevas calles o plazas) en la medida en que no afecte a la trama histórica, que identifica con la estructura fundamental o básica, sino a la otra secundaria sin vocación de permanencia ${ }^{49}$. Se debe tener en cuenta que

FD 4. ${ }^{\circ}$ : "La aplicación de esta doctrina al caso que ahora se contempla hace necesario indicar:

A) Esta Sala ha puesto ya de relieve con anterioridad que «la racionalidad del planeamiento no se circunscribe a la exigencia de una ordenación con criterios estrictamente funcionales con proyección de futuro sino que alcanza también a la conservación de los elementos que reflejan la historia de la ciudad» - S. 11-2-1991.

B) Y si esto es así con carácter general mucho más ha de serlo en un Plan Especial como el litigioso que aspira al «mantenimiento de la estructura urbana histórica» evitando la destrucción «no sólo de aquellos elementos con excepcional valor histórico o artístico sino también de los que configuran ambientalmente la trama, aún sin grandes valores individuales»-Memoria, pág. $26^{-}$.

Así las cosas, ninguna irracionalidad se aprecia en el Plan litigioso por la conservación de lo que el demandante estima eran «estrechas y viejas calles medievales»".

Sin $n^{\circ}$ recurso, RJ 1989/3847.

"SEGUNDO.- El artículo 23.3 de la vigente Ley del Suelo - dice como es sabido- que «cuando se trate de operaciones de reforma interior no previstas en el Plan general, el Plan especial (de reforma interior) no modificará la estructura fundamental de aquéb. Esto implica - como ha dicho ya en diversas ocasiones este Tribunal Supremo, y la Sala de primera instancia lo ha recordado también en su sentenciaque el límite que ha de respetar todo Plan especial de reforma interior es la estructura fundamental del Plan general. Respetando este límite, el Plan especial de que se trata puede proceder a reorganizar el suelo en la forma que el interés general, definido en sus líneas generales en el Plan general, exïa. La expresión "estructura fundamental" envuelve un concepto legal indeterminado que, por lo pronto, tiene que precisarse en relación a ese Plan general, y sólo en cuanto éste la respete a la trama urbanistica existente. $Y$, por eso, la previsión en un Plan especial de reforma interior de apertura de nuevas calles o de plazas no implica necesariamente la incorrección jurídica invalidante de éste, ya que puede muy bien ocurrir que la apertura de esas nuevas calles o plazas no altere para nada 
esta Sentencia se dicta antes de la regulación de patrimonio cultural valenciana, esto es, a la vista del art. 21 LPHE, aunque no lo estudie ni mencione (lo que origina cierta confusión argumental, a mi juicio, entre la estructura fundamental del plan general que el plan especial no puede franquear, y lo que es la trama histórica, esencial para la conservación del conjunto), por lo que se trata de un pronunciamiento relevante también para las conclusiones del epígrafe siguiente.

\section{b) La modificación de la estructura urbana en los planes especia- les de conjuntos históricos}

La regulación de patrimonio histórico y cultural contiene una sutil tensión entre el mantenimiento de la estructura urbana de los conjuntos históricos, imponiendo la conservación de las alineaciones urbanas existentes (hasta la aprobación del plan especial en todo caso, art. 20. 3 LPHE, y tras éste permitiendo al tiempo excepcionalmente sustituciones de inmuebles, en el art. 21. 3 LPHE), y de otro lado su mejora en remodelaciones urbanas en plan especial por razones excepcionales de habitabilidad (art. 21. 2 LPHE en general y art. 21. 3 LPHE, en el supuesto de sustitución de inmuebles, y art. 56 LPCAst, art. 15.1 LPCMur y art. 39. 3 LPHIB, en términos similares), tensión que se ha trasladado, como se verá, a la jurisprudencia. Alguna legislación autonómica ${ }^{50}$ precisa el inquebrantable objetivo de mantenimiento de la estructura urbana mediante la preservación de alineaciones, volúmenes y edificabilidad, permitiendo a su vez excepcionar ésta (por tanto expresamente con modificación de alineaciones) siempre que ello no altere aquel objetivo esencial de conservación de la es-

esa estructura fundamental, por afectar a zonas que conforme a las previsiones del Plan general forman parte de la estructura secundaria, esto es no principal, no básica, carente de la vocación de permanencia que es propia sólo de la estructura fundamental.

TERCERO.- Establecido lo anterior y puesto en relación con la legalidad urbanística vigente en Valencia y su comarca es patente que las previsiones de apertura de nuevas calles y de plazas que se prevén en el Plan especial de reforma especial denominado Dels Velluters o del Pilar no modifica la estructura fundamental del Plan general, ni rompe la coherencia de éste. Porque -tal como quiere el Plan general- respeta la trama histórico-artística del suelo a que se refiere e incluso la recobra y la realza mediante la demolición de inmuebles que han alcanzado un grado de deterioro irreversible." (cursiva en negrita en el original).

Una perspectiva crítica con la regulación general autonómica, L. POMED SÁNCHEZ, "La Ley del Patrimonio cultural Aragonés en el concepto competencial", en Estudio sistemático de la Ley del Patrimonio Cultural Aragonés, 2001, pp. 19-54, en concreto, pp. 52-54. 
tructura urbana, y configura una aplicación simultánea de los principios de conservación y habitabilidad ${ }^{51}$, más compleja de articular pero más certera ${ }^{52}$, que la establecida en la legislación estatal (y similar de Asturias, Murcia e Islas Baleares), si se interpretara que el art. 21. 3 LPHE impediría cualquier modificación de alineaciones en sentido estricto ${ }^{53}$.

$\mathrm{El}$ art. 30, apdo. a) LPHMa, entre el contenido de los planes especiales, incluye normas sobre el mantenimiento general de la estructura histórica, y el art. 33 LPHMa impide la modificación de alineaciones en conjuntos y entornos sin plan especial, por lo que, a contrario, parece admitirlas si procedieran; en similar regulación los arts. 52.1 y 53. 1 LPCHARio, y el art. 28. 2 LPCPV, que sólo prohíben modificar alineaciones sin plan especial; el art. 12, apdos. 2 y 3 , LPHC-LM determina una genérica armonía entre la conservación y las necesarias adecuaciones edificatorias; la opción expresa de excepcionales remodelaciones que contribuyan a la mejora y conservación del conjunto se establece en el art. 35. 2, a) LPCCat, art. 46. 2 LPHGa, art. 41. 2 LPHEx, art. 34. 2 LPCanar, art. 39.2, a) LPCVa, art. 39. 2 LPGNa, art. 42. 4 LPCGyL, arts. 53. 2 y 63. 1 LPCGant, art. 43. 3, a) LPGAr, y art. 31. 2, a LPHAnd.

Ya la doctrina ha señalado cómo la modificación de alineaciones puede resultar acertada en algunos casos para la mejora del conjunto. Vid. en este sentido la exposición de G. BARRERO RODRÍGUEZ: La ordenación urbanistica de los conjuntos históricos, 2006, pp. 227-231, para quien el objeto de protección del art. 21. 3 LPHE es sólo la trama histórica y no el resto de alineaciones posteriores, por lo que valora favorablemente la regulación de las Comunidades que permiten las remodelaciones, porque, según expone, en determinados casos la alteración de alineaciones permitiría conservar precisamente la trama urbana degradada o desaparecida. También J. GARCÍA-BELLIDO: "Problemas urbanísticos de la Ley del Patrimonio Histórico Español: un reto para el urgente desarrollo legislativo autonómico", Ciudad y Territorio n ${ }^{\circ}$ 78, 1988, p. 11, circunscribió el art. 21. 3 LPHE a la protección de la trama histórica; y en sentido similar, I. SÁNCHEZ RUIZ DE VALDIVIA, "La protección jurídica de los Conjuntos históricos: ¿ crealidad o quimera?", en La protección jurídica del patrimonio inmobiliario histórico, 2005, dir. Martín Almagro-Gorbea/Antonio Pau, pp. 59-185, en concreto p. 119.

Vid. en contra, Tomás-Ramón FERNÁNDEZ: "La ordenación urbanística de los Conjuntos Históricos: breve denuncia de los excesos al uso", en Nuevas perspectivas del régimen local. Estudios homenaje al profesor Boquera Oliver, Liment-Barberá y Baño León, coord., 2002, pp. 1267-1279. A juicio del autor, la inalterabilidad de las alineaciones sólo tiene sentido en los conjuntos históricos de valor excepcional y no en el resto. Esta lectura le lleva a propugnar (p. 1279) una interpretación acorde a la finalidad de la norma y en su contexto social del art. 3 del Código Civil para depurar esos excesos, lo que, a mi juicio, no deja de resultar extraño si la norma realmente impidiera la alteración de alineaciones, que creo es en lo que se puede disentir, y en cualquier caso se debe aplicar en virtud del principio de vinculación de las normas en el Estado de Derecho. En sentido similar, a mi juicio, se debe respetar la excepcionalidad de las remodelaciones urbanas determinada por el legislador, aunque alguna autorizada doctrina también recurre al mismo art. 3 Código Civil (vid. J. VICENTE DOMINGO, "Consideraciones críticas so- 
Estas cuatro normas podrían adolecer en apariencia de la carencia de regulación completa o bien contienen una antinomia, ya que exigirían conservación de alineaciones aunque aceptan remodelaciones urbanas. ¿Qué remodelaciones urbanas se admiten, sólo las que no supongan modificación de alineaciones? ¿Es eso remodelación urbana o mera sustitución de edificios? Si son lo mismo, por qué utiliza el legislador dos términos: remodelación urbana y sustitución de inmuebles? La respuesta a esta posible aparente antinomia o laguna es trascendental también para una adecuada lectura y aplicación de las demás normas de las comunidades autónomas que sí permiten la modificación de alineaciones en las excepcionales remodelaciones que contribuyan a la mejora del conjunto, ya que esas normas, según mi criterio y mayoritario de la doctrina, se incardinan en el mismo supuesto y deben respetar la LPHE (STC 17/1991, FD 3. $\left.{ }^{\circ 54}\right)$.

bre la política protectora de los Conjuntos Históricos" Revista de Derecho Urbanístico n ${ }^{\circ} 122,1991$, pp. 144-145. El mismo autor, en Guía jurídica del patrimonio cultural de Castilla y León, p. 163, propugna una cierta dinámica de renovación de la trama urbana necesaria y admisible. Frente a estas tesis, A. GONZÁLEZ SANFIEL, "Problemas en la planificación de los conjuntos históricos (A propósito de su regulación en Canarias)", en El Derecho urbanístico en el siglo XXI: homenaje al profesor Bassols Coma, 2008, vol. 3, pp. 173-234, en concreto p. 217, estima que la versión más permisiva de las comunidades autónomas supone "un margen demasiado amplio y peligroso para considerarlo garantista del valor cultural". En una dirección paralela, el estudio de J. LÓPEZ JAÉN "Sobre los conjuntos históricos españoles", en la revista Ciudad y Territorio: estudios territoriales, $\mathrm{n}^{\circ}$ 85, 1990 (3), pp. 57-66, en concreto p. 62, estima que la cifra de ciudades españolas que satisfarían las condiciones que la definición legal señala rondaría las 1100 ó 1200, y la realidad está muy por debajo de esa valoración cultural.

Se discute en la doctrina el alcance de esta regulación estatal. Un estudio detallado sobre el supuesto de las alineaciones lleva a cabo C. BARRERO RODRÍGUEZ, La ordenación urbanística de los conjuntos históricos, 2006, pp. 83-101, en la que con gran objetividad expone cómo la STC 17/1991, en lectura conjunta con la STC 61/1997 sobre urbanismo, no ha resuelto la aplicabilidad de las normas de planeamiento de los arts. 20 y 21 LPHE (en definitiva la extensión de la competencia normativa del Estado sobre expolio del patrimonio histórico) a las comunidades autónomas, de forma que cabrían dos interpretaciones: se trataría de normas vinculantes que constituirían un límite infranqueable a las comunidades autónomas o bien legislación que excede de su ámbito competencial, que se podría modificar o desplazar por aquéllas. Y lo demás, efectivamente, son opiniones de los expertos en Derecho, como expone la autora, p. 100. M $\mathrm{M}^{\mathrm{a}} \mathrm{R}$. ALONSO IBÁÑEZ, El patrimonio histórico. Destino público y valor cultural, 1991, p. 91 parte igualmente de la incertidumbre de la STC 17/1991. Posteriormente esta autora, en "Normas materiales de ordenación urbanística. A propósito de las remodelaciones urbanas en conjuntos históricos", en el Derecho Administrativo en el umbral del siglo XXI: homenaje al Profesor Ramón Martín Mateo, 2000, Sosa Wagner dir., pp. 3323-3339, en concreto pp. 3335-3339, expone cómo el legislador estatal, erróneamente a su juicio, no consideraría la regulación de conjuntos en el ámbito de su competencia del art. 149. 1, 28. ${ }^{\text {a }}$ Const., y ello con base en la interpretación del supuesto de $e x-$ 
En todo caso, a mi juicio, se requiere una interpretación del art. 21 LPHE. Lo cierto es que en este caso, la transcendencia del carácter vinculante o no de la legislación estatal se derivaría de una determinada lectura del art. 21. 3 LPHE que presume la aplicación de la inalterabilidad de las alineaciones, a las remodelaciones urbanas del supuesto del art. 21. 2 LPHE. Esta premisa debe ser reconsiderada a la vista, entre otras, de la STS de 8-5-1989 y sobre todo de las SSTS de 12 y 13 de marzo de 2008 (que se expondrán aquí infra), esto es, la LPHE no impondría tal limitación más que cautelarmente, antes de

polio que habría realizado el mismo legislador en el RD 64/1994, sólo ante la inactividad de la comunidad autónoma, por lo que a tenor de esa interpretación del legislador estatal resultaría de aplicación supletoria.

El carácter vinculante de estos preceptos se ha expuesto por L. PAREJO ALFONSO, "Urbanismo y patrimonio histórico" en la Revista Patrimonio cultural y Derecho, n 2, 1998, pp. 55-79, porque delimita el contenido básico del derecho de propiedad, en concreto p. 70, respecto a las prescripciones sobre alineaciones, edificabilidad, parcelaciones y agregaciones, que las relaciona entre las "determinaciones sustantivas de ordenación de directa aplicación" y A. MENÉNDEZ REXACH: "Los planes especiales de protección del patrimonio histórico" en Urbanismo y patrimonio histórico, 1999, pp. 184-195, en concreto, pp. 193-194.

También se han pronunciado en general sobre la legislación de patrimonio histórico inequívocamente a favor de su aplicabilidad directa, S. MUÑOZ MACHADO, Derecho público de las Comunidades Autónomas, 1982, vol. I, pp. 590 ss., y E. GARCÍA DE ENTERRÍA, "Consideraciones sobre una nueva legislación sobre el patrimonio artístico, histórico y cultural" en Revista Española de Derecho Administrativo n ${ }^{\circ} 39,1983$, pp. 586 ss, de forma previa a la LPHE, y con posterioridad, A. PÉREZ DE ARMIÑÁN, Las competencias del Estado sobre patrimonio histórico español en la Constitución de 1978, 1997, pp. 35-98, entre otras, pp. 51-52 que se refiere a la LPHE que puede ser completada pero no sustituida por las normas autonómicas, pp. 60-61, y pp. 95-97, en las que propugna una eventual reforma, aunque no necesaria tras la STC 17/1991, de la LPHE que, dado el ámbito material de una competencia concurrente, precise su carácter indisponible. Diversos supuestos se exponen por M. ALEGRE ÁVILA, "Patrimonio histórico y comunidades autónomas", Revista civitas de Derecho Administrativo, n 121, 2004, pp. 49-66, en concreto pp. 60-61, que parte de la vinculación de la legislación estatal.

Sobre el carácter no vinculante de los mencionados preceptos se pronuncia la Sentencia del Juzgado de lo Contencioso-Administrativo de Santa Cruz de Tenerife de 15-12-2006 ( ${ }^{\circ}$ St. 389/2006) respecto a la normativa canaria que no recoge la prohibición estatal de parcelaciones, agregaciones o agrupaciones de parcelas, con la argumentación de que se habría producido un desplazamiento de la normativa estatal en la materia al amparo de la competencia exclusiva autonómica (FD 7. ${ }^{\circ}$, como recoge A. GONZÁLEZ SANFIEL, ob. cit. pp. 217-218. Este autor, sin embargo, la valora como una resolución desafortunada, al partir de que las normas estatales serían vinculantes.

J. M ABAD LICERAS, Administraciones locales y patrimonio histórico, pp. 21-24, diferencia en la aplicación de la LPHE un contenido aplicable con carácter principal y otro supletorio, cuando no se trate de exportación o expoliación, y no haya norma en las Comunidades. 
aprobar el plan especial, y vigente éste, para las meras sustituciones de inmuebles que no se enmarquen en una operación de remodelación urbana con objeto de mejorar y conservar el conjunto (que además no perjudique a la trama histórica). Dicho eso, efectivamente, a mi juicio, la legislación de patrimonio histórico del Estado es vinculante y aplicable en todas las comunidades autónomas, y se impone a su legislación urbanística y de patrimonio histórico o cultural, con base en sus competencias sobre expoliación, exportación, cultura y delimitación básica del derecho de propiedad, entre otras.

Posiblemente, la supuesta antinomia y tensión con la legislación de las comunidades autónomas, se resuelve clarificando el supuesto. El legislador, según mi criterio, estaría definiendo tres supuestos: primero, impide modificar las alineaciones antes de aprobar plan especial (art. 20. 3 LPHE y correlativos de las Comunidades), como se ha expuesto aquí supra II; además (segundo supuesto), una vez aprobado el plan, en el caso de meras sustituciones puntuales de inmuebles (sin remodelación urbana), se establece su excepcionalidad y ahí sí, esa situación se restringe con la obligación de mantener las alineaciones y volúmenes y edificabilidad (art. 21. 3, segunda frase, LPHE) ${ }^{55}$, evitando que mediante intervenciones individuales no planificadas se pueda alterar el carácter del conjunto; sin perjuicio de que (tercer supuesto, art. 21. 2 con respeto a la estructura urbana, esto es a la trama histórica o estructura básica del Conjunto, art. 21. 3, primera frase, LPHE) se admitan excepcionalmente remodelaciones urbanas "sólo en caso de que impliquen una mejora de sus relaciones con el entorno territorial urbano o eviten los usos degradantes para el propio Conjunto", en las que, según mi criterio, sí se podrían modificar alineaciones siempre que no suponga una modificación de la estructura urbana (art. 21. 3, ab initio, LP$\mathrm{HE}$ ), es decir, serían modificaciones puntuales no significativas que se justifican en la propia conservación del Conjunto. Esta excepcionalidad en la aplicación general de estos dos últimos supuestos exigirá prudencia y especial motivación.

El tercer supuesto mencionado de remodelaciones urbanas (art. 21. 2 LP$\mathrm{HE}$ ), a su vez, puede ser objeto de dos interpretaciones: cuando haya remode-

En este sentido, J. VICENTE DOMINGO: "Consideraciones críticas sobre la política protectora de los conjuntos históricos", Revista de Derecho Urbanístico n ${ }^{\circ} 122$, 1991, pp. 115-162, en concreto p. 141, estima que la limitación del art. 21. 3 LPHE es sólo para la sustitución de inmuebles, en interpretación literal del precepto, además de que sustancialmente tampoco parece posible tal remodelación sin afectar a las alineaciones. En contra vid. P. BENSUSÁN MARTÍN: La protección urbanística de los bienes inmuebles históricos, 1996, p. 229. 
laciones urbanas ("sólo en caso de que impliquen una mejora de sus relaciones con el entorno territorial urbano o eviten los usos degradantes para el propio Conjunto"), esa actuación más profunda y justificada que una mera sustitución de un inmueble, permite una cierta modificación de alineaciones, prudente, motivada y excepcional, siempre que no perjudique a la trama histórica o estructura básica del Conjunto (art. 21. 3, primera frase, LPHE); o bien, en interpretación a mi juicio demasiado forzada, serán admisibles las remodelaciones urbanas con cambio excepcional de las alineaciones, siempre que no supongan, además, sustitución de edificios (por tanto sólo si afectan a espacios libres), porque en ese caso se integrarían el tercer y segundo supuestos (apdos. 2 y 3, segunda frase, del art. 21, LPHE, respectivamente), y se tendrían que mantener las alineaciones que causaran sustitución de inmuebles. Según esta segunda interpretación, el tercer supuesto (art. 21. 2 LPHE) en interpretación conjunta con el apdo. 3, segunda frase, del mismo art. 21 LPHE, parecería requerir, que se tratara de remodelaciones que, en ese caso de alteración de alineaciones, no supusieran adicionalmente sustitución de inmuebles, porque entonces se aplicaría la anterior cautela. Esta lectura, sin embargo, no respeta la delimitación de supuestos legales ya que en ese apartado $3 .^{\circ}$ del art. 21, segunda frase, LPHE, se determina, según mi criterio, la mera sustitución de inmuebles sin que incluya el plan más consideraciones basadas en remodelaciones necesarias para conservar el Conjunto, porque en este caso ya resultaría aplicable el supuesto del apartado $2{ }^{\circ}$ del mismo art. 21 LPHE. Se debe observar que si bien el legislador podría haber mejorado la redacción (al menos probablemente la sistemática, e invertir el orden, primero determinando los supuestos de sustituciones aisladas de inmuebles permitidas en plan especial y sólo después las remodelaciones en plan especial), esa previsión del art. 21. 3, segunda frase, LPHE, sólo viene a reiterar lo especificado para las meras sustituciones antes de plan especial (art. 20.3 LPHE).

Esto es, a mi juicio, el legislador impide que las meras sustituciones, antes o después del plan (que en estos supuestos no añadiría nada) se acompañen de alteración de edificabilidad; sin embargo, lo que realmente adicionaría el art. 21. 2 LPHE es la posibilidad de que un plan especial articule una remodelación con objeto de mejorar el Conjunto ("sólo en caso de que impliquen una mejora de sus relaciones con el entorno territorial urbano o eviten los usos degradantes para el propio Conjunto") y en este supuesto sí sería admisible la modificación así justificada de alineaciones puntuales, entiendo que sin perjudicar a la estructura básica de la ciudad histórica, esto es, a la trama histórica (art. 21.3, primera frase, LPHE).

Sólo en la primera interpretación dada del tercer supuesto (art. 21. 2 LPHE) tendría, además, cabida el resto de normas de las Comunidades, que han diferenciado, la sustitución de inmuebles manteniendo alineaciones, volúmenes 
y edificabilidad, de aquellas remodelaciones urbanas excepcionales si contribuyen a la mejora de la conservación del conjunto (que no afecte a la estructura o trama histórica), en los términos de las SSTS de 12 y 13 de marzo de 2008 (que se exponen infra), esto es, mínimo imprescindible, por calidad ambiental y habitabilidad del espacio del conjunto, el diseño condicionado por su valor histórico, integración de la ciudad en el barrio, mantenimiento de la altura de las edificaciones -en este caso-, y de la unidad del barrio; sin más limitaciones, en definitiva, sin impedir que además las modificaciones de alineaciones supongan sustitución de inmuebles. Estas Comunidades habrían acogido entonces la primera de las interpretaciones mencionadas, y en el mismo supuesto, en las normas de Asturias, Murcia e Islas Baleares, estarían a lo que resulte de la interpretación de la norma estatal que, a mi juicio (STC 17/1991, FD 3. ${ }^{\circ}$ ), es legislación aplicable en todo (competencia del) el Estado.

Si bien es indiscutible que el Tribunal Constitucional no ha resuelto explícitamente la extensión de la competencia estatal sobre legislación en materia de planeamiento de protección de Conjuntos (arts. 20 y 21 LPHE) ${ }^{56}$, en mi opinión, sí resultaría implícita la delimitación de la competencia legislativa en la materia y en consecuencia su carácter vinculante (de toda la LPHE), en la referencia (Sentencia 17/1991, FD 3. ${ }^{\circ}$ ) a la competencia legislativa del Estado que puede requerir tratamientos generales o un conjunto de medidas de defensa que se extienden a la defensa frente a la destrucción o despojo e incluyen un plus de protección que permita la preservación de los valores o fines de este patrimonio. A mi juicio el Tribunal Constitucional, al hilo de la impugnación del concepto de expolio del patrimonio histórico del art. 4 LPHE, cuya base argumental no se olvide está en la delimitación de una materia competencial central (art. 149. 1. 28. ${ }^{a}$ de la Const.), estaría refiriéndose a la constitucionalidad de toda la Ley 16/1985, pues en sus términos el Tribunal alude a legislación, y no sólo a la definición de las competencias ejecutivas de gestión en casos concretos de expolio por inactividad de las comunidades autónomas. En todo caso, también parece que estos concretos preceptos (arts. 20 y 21 LPHE) contendrían medidas con objeto de defender este patrimonio además de garantizar su finalidad ${ }^{57}$, por lo que se subsumen en el pronunciamiento del

\section{BARRERO RODRÍGUEZ, La ordenación urbanística..., ob. cit., loc. cit.}

En una argumentación similar con ocasión del análisis de la competencia del Estado sobre el establecimiento de las dos categorías de protección, BIC y catalogados, objeto de pronunciamiento en la misma STC 17/1991, FD 10- ${ }^{\circ}$, vid. J. GARCÍA FERNÁNDEZ, Estudios sobre el Derecho del patrimonio histórico, 2008, p. 154: “...Este, por su parte señaló que la calificación de BIC... 
Tribunal acerca de su consideración como ámbito material de la competencia legislativa del Estado. Otra cosa será si efectivamente estos preceptos están en contradicción con la regulación de las Comunidades que permiten la modificación de alineaciones mediante plan especial en casos excepcionales de remodelaciones urbanas en la medida en que lo requiera su mejor conservación, lo que a mi juicio como se ha expuesto, está incluido en el art. 21.2 y art. 21. 3, primera frase, LPHE, con las cautelas mencionadas. De forma que, al menos en esta cuestión, los supuestos de los arts. 20 y 21 LPHE en todas las comunidades autónomas no resultan modificados sino clarificados en las normas de las Comunidades.

De ahí no se deriva la existencia de un portillo que permita la modificación arbitraria de alineaciones en planes especiales, sino, una posibilidad excepcional que sólo estará justificada en determinados casos cuando se atienda mejor a la conservación del Conjunto evitando usos degradantes y a su integración con su entorno urbano, en tanto no perturbe la trama histórica o estructura básica del Conjunto, sino que su objeto sea precisamente su mejor conservación, sólo, por tanto, en los prudentes términos que había sido sugerido por la mejor doctrina ${ }^{58}$, sin que resulte a mi juicio procedente aquí una interpretación con base en una lectura acorde con la teleología del precepto o su contexto social, que no puede ser otro que lo preceptuado en la LPHE, aunque nos pueda parecer excesivo, aunque todas las propuestas sean oportunas de lege ferenda.

Como se expondrá, el mismo Tribunal Supremo en recientes sentencias (SSTS 12 y 13 de marzo de 2008) ha confirmado la legislación de las Comunidades que admite la modificación de alineaciones, sin circunscribirla a supuestos que no sean de sustitución de inmuebles, con base además en la citada STS de 8-5-1989 que expresamente admitía la remodelación urbana en plan especial si no afectaba a la trama histórica o estructura básica o fundamental.

constituye un requisito para que puedan gozar de singular protección y tutela y, por ello, es también un requisito para su defensa contra la exportación y la expoliación. Este es efectivamente, el título habilitante que justifica que el Estado establezca, por Ley, las categorías de protección pues sin éstas es difícil adoptar medidas contra la expoliación y más difícil aún es gestionar el régimen de exportación...".

C. BARRERO RODRÍGUEZ, La ordenación urbanística..., 2006, ob. cit. pp. 227-231, y en la reciente valoración de esta materia en la LPHAnd, en "Innovaciones de la Ley 14/2007...", Revista Andaluza de Administración Pública, n 68, pp. 73-111, 2007, p. 87. 
A mi juicio, una vez que se considera que las normas de las Comunidades tienen que respetar el art. 21 LPHE (STC 17/1991, FD 3. ${ }^{\circ}$ ), y que el Tribunal Supremo las ha aplicado sin discutir su constitucionalidad en dos Sentencias de 2008, como se expone a continuación, deberá concluirse ${ }^{59}$ que tal pronunciamiento del Tribunal Supremo supone indirectamente la confirmación de la interpretación aquí propuesta, esto es, el supuesto del art. 21. 2 LPHE se delimita de forma independiente (no adicionada en ningún caso) al del apdo. 3, segunda frase, del mismo art. 21 LPHE, permitiendo en consecuencia las remodelaciones urbanas (sustitución de inmuebles, alteración de alineaciones), que podrán incluir en su caso modificación de alineaciones que requieran sustitución de edificaciones si no se afecta a la estructura básica de la ciudad histórica (que contribuyan a la conservación del conjunto y no perjudiquen a la trama histórica), de conformidad con los apdos. 2 y 3, art. 21 LPHE.

Parece necesario hacer una exposición de esta jurisprudencia, con sentencias en las que se ha mostrado una interpretación extensiva del art. 21. 3, segunda frase, LPHE y otras más centradas en preservar el objetivo de la conservación de la estructura urbana permitiendo alteraciones puntuales y motivadas de alineaciones, aunque con base en regulación de las Comunidades más acabada. Podría tratarse también de dos líneas jurisprudenciales, pero, tal como aquí se aprecia, indicarían más bien una evolución en la doctrina del Tribunal Supremo.

b, 1) La posición original del Tribunal Supremo de estricta inalterabilidad de las alineaciones en conjuntos históricos

Así, de un lado el art. 20. 3 LPHE impone la conservación de las alineaciones en tanto no se apruebe el plan especial; y a su vez, el art. 21. 3 LPHE declara terminantemente la conservación de la estructura urbana en los conjuntos y, en todo caso, el respeto a las alineaciones existentes, por lo que en interpretación extensiva sería una obligación también aplicable una vez aprobado el plan especial, al menos cuando haya sustitución de inmuebles, se trate o no de remodelaciones urbanas. Esta lectura no circunscribiría esta limitación sólo a los supuestos de sustitución puntual de inmuebles sino también, erróneamente a mi juicio, a los enmarcados en una remodelación urbana planificada y justificada en la propia conservación del conjunto.

Y salvo que se interprete que el Tribunal Supremo no se ha planteado el problema más que desde la perspectiva de la regulación de las Comunidades, y sin que discuta su competencia para regular de otra forma sobre la materia. 
En aplicación extensiva de la conservación de alineaciones preceptuada en los arts. 20. 3 y 21. 3 LPHE, sólo se ha pronunciado la STS 5-3-1999 (rec. n ${ }^{\circ}$ 1857/1993) que confirmó la Sentencia de instancia (del TSJ Andalucía de 31-7-1992 ${ }^{60}$ ) que anuló la aprobación definitiva de la revisión de un plan general (Sevilla) que con el contenido típico de plan de protección (lo que es avalado por el Tribunal frente al recurso) preveía la modificación puntual de la alineación de la Calle Céspedes de Sevilla. El pronunciamiento del Tribunal es contundente, y en su argumentación no se diferencian los supuestos tal y como aquí se ha propuesto (meras sustituciones admisibles según el plan que no podrán alterar alineaciones, volumen o edificabilidad, frente a otras remodelaciones urbanas más complejas y justificadas "sólo en caso de que impliquen una mejora de sus relaciones con el entorno territorial urbano o eviten los usos degradantes para el propio Conjunto", que sí podrían articularlas). Al contrario, el Tribunal, confirma la STSJ de Andalucía de 31-7-1992 y ambas realizan una interpretación del art. 21. 3 LPHE extensiva, esto es, imponiendo la limitación de alteración de alineaciones establecida para la sustitución de inmuebles del apartado $3 .^{\circ}$, segunda frase, también a las remodelaciones del apartado $2 .^{\circ}$, del art. $21 \mathrm{LPHE}^{61}$.

Un comentario sobre estas Sentencias, en C. BARRERO RODRÍGUEZ: "La alteración de alineaciones en los Conjuntos Históricos. La interpretación del artículo 21. 3 de la Ley del Patrimonio Histórico Español (a propósito de la Sentencia del Tribunal Supremo de 5 de marzo de 1999)" en la Revista Patrimonio Cultural y Derecho n ${ }^{\circ} 3$, 1999. La autora considera que la regla de inmutabilidad de alineaciones carece de fundamento en los casos de ensanches de los últimos años, por lo que propone diferenciar en su interpretación los supuestos en los que el valor cultural exige la intangibilidad de las alineaciones de esos otros en los que su tutela precisamente requiere su modificación.

"CUARTO.- La finalidad de protección de la Ley 16/1985 se intensifica cuando la misma se ocupa de Conjuntos históricos ya que excepcionalmente permite remodelaciones urbanas en ellos pero sólo -según reza su artículo 21.2- en caso de que impliquen una mejora de sus relaciones con el entorno territorial o urbano o eviten los usos degradantes para el propio Conjunto.

De la misma forma -según el artículo 21.3 de la calendada Ley- la conservación de dichos conjuntos comporta el mantenimiento de la estructura urbana y arquitectónica, así como de las características generales de su ambiente. Es en este contexto normativo en el que se inserta el precepto que se discute en esta casación. La Ley dispone que se considerarán excepcionales las sustituciones de inmuebles, aunque sean parciales, y que sólo podrán realizarse en la medida en que contribuyan a la conservación general del carácter del conjunto. Elevando aún más el nivel de protección se obliga a mantener las alineaciones urbanas existentes, precisando el inciso final del precepto que dicho mantenimiento se hará «en todo caso»; es decir, «siempre». 
La STS 29-3-2004 (rec. n 6067/2001) también ha considerado que prima facie no es posible (tampoco tras la aprobación del plan especial) modificar la estructura urbana y arquitectónica ni las alineaciones, si bien hay que contextualizar este pronunciamiento en el caso resuelto, dado que se trataba de una modificación de alineación interior o fondo del edificio, que el Tribunal diferencia de las alineaciones exteriores a las que se referirían los arts. 20.3 y 21 . 3 LPHE. El caso merece un especial detenimiento, porque una vez que el Tribunal aprecia tal punto de partida, sin embargo va a referirse a continuación a la posibilidad de atender a las necesidades sociales de habitabilidad de las viviendas en el conjunto y de modificaciones que no afecten a la estructura urbana ni arquitectónica ni a las características generales del ambiente (aunque parece que esta perífrasis del Tribunal no engloba la alteración de alineaciones). Se trataba de la impugnación de la previsión en un plan general con objetivos y criterios para un futuro plan especial, que aquél califica (FD $10 .^{\circ}$ ) de plan mixto, y participa a la vez de la naturaleza propia de los planes de protección (art. 20. 1 LPHE) y reforma interior (art. 23 TRLS 1992). Sin embargo el Tribunal duda de tal calificación a la luz del previsible contenido del plan especial, aunque sólo tiene a su vista las determinaciones impugnadas: previsión de más viviendas, regularización de alineaciones interiores, cierres de manzana, avances sobre espacios libres de parcela, usos de oficinas públicas. Estas determinaciones, al menos, considera el Tribunal, no suponen verdadera reforma interior del art. 23 TRLS 1992, por lo que su análisis lo hace a la luz exclusivamente de la LPHE. En primer lugar expone las determinaciones y las limitaciones de los planes especiales de protección, más apegado a la letra de los arts. 20. 3 y 21. 3 LPHE y la intangibilidad de la estructura urbana en los conjuntos históricos, aunque admite (óbiter dictum) la alteración de alineaciones en plan especial ${ }^{62}$.

El sentido gramatical del texto es inequívoco, no pudiéndose apreciar que su mandato sea contrario a la finalidad propia de la norma, atendida la naturaleza misma de un conjunto histórico como Bien de Interés Cultural, tal como lo define la propia Ley en su artículo 15.3. La interpretación literal es, por ello, suficiente y obligada." (cursiva no original).

Las posibles dudas sobre si extiende o no la prohibición a supuestos de remodelaciones urbanas se desvelan con la lectura de la STSJ de Andalucía citada de 31-7-1992 en la que se basa: “...Ahora bien, el legislador ha querido elevar aún más el nivel de protección de estos bienes de interés cultural, hasta el punto de obligar, en todo caso, a mantener las alineaciones urbanas existentes, de forma tal que la posible remodelación que en un Conjunto Histórico permite el número 2 del artículo 21 LPHE siempre encontrará la limitación de tener que conservar y mantener inmodificables las alineaciones preexistentes...".

“... Estos Planes Especiales, cuya finalidad es proteger una determinada área, han de contener las siguientes determinaciones, según el artículo 20.2 .. tienen las siguientes limitaciones:... 
Y en la argumentación del Tribunal habría sido suficiente con la alusión a que tales determinaciones en su caso (ya que no se pueden ahora analizar pues no se recogen en la Sentencia) no suponen modificación de las alineaciones exteriores, pero continúa su argumentación con la referencia a un concepto metajurídico, a la "rehabilitación integrada", "con la finalidad de recuperación de área residencial y de las actividades económicas", en una argumentación, innecesaria a mi juicio, toda vez que la solución del caso que interesaba tenía cabida prima facie en los arts. 20. 2 (sustitución de inmuebles) y en el art. 21. 3 LP$\mathrm{HE}$, si no modificaba las alineaciones exteriores, y porque el Tribunal se refiere a excepcionales modificaciones, de sustitución de inmuebles y actuaciones que no afectarían a la estructura urbana ni arquitectónica ni a las características generales del ambiente ${ }^{63}$. Además parece que la base de tal concepto se encuentra sin duda en las áreas de rehabilitación integrada del art. 20. 2 LPHE, establecidas con la mera finalidad de articular incentivos económicos.

$4^{\text {a }}$--En todo caso se mantendrán las alineaciones urbanas existentes (artículo 21.3).

$5^{\text {a }}$ - - Hasta la aprobación del Plan Especial no se permitirán alineaciones nuevas, alteraciones en la edificabilidad, parcelaciones ni agregaciones (artículo 20.3, in fine)..." (FD 10. ${ }^{\circ}$ ).

El Tribunal parece admitir (a contrario limitación 5. ${ }^{\mathrm{a}}$ ) la modificación de alineaciones mediante plan especial.

“...Esas modificaciones (y las conexionadas con ellas) tienen la finalidad, directa en unos casos e indirecta en otros, de recuperar el índice de densidad humana, criterio éste que ya se encontraba en el Plan General originario, como forma de evitar el despoblamiento del Recinto Amurallado. Este criterio de aumento de la densidad, que parece ser mirado con disfavor jurídicamente por la Sala de instancia, responde a un designio de política urbanística, de naturaleza metajurídica, que, en la medida en que respete las limitaciones y persiga los objetivos legalmente fijados, es tan aceptable jurídicamente como cualquier otro.

Pues bien, las modificaciones de que se trata tienen su justificación en el concepto de rehabilitación integrada que permite el artículo 20.2 LPH, con la finalidad de recuperación del área residencial y de las actividades económicas adecuadas.

Y ni el aumento del número de viviendas ni el uso de oficinas en todas las plantas del edificio, ni la regularización de alineaciones interiores (que no son las alienaciones urbanas que el artículo 21.3 ordena mantener, como líneas exteriores de separación de los solares y la vía pública), ni los cierres de manzana sin aumento de superficie construida o de ocupación, ni, finalmente, las nuevas determinaciones sobre usos son medidas urbanísticas que supongan en sí mismas consideradas una dislocación de la estructura urbana ni arquitectónica del Conjunto ni de las características generales del ambiente, sino que tienen su apoyo en el concepto de «rehabilitación integrada».

Respecto de los derribos, la modificación núm. 10 se limita a perfeccionar y limitar la norma 2.3.c) del Plan General, que ya las permitía. Se prescribe ahora que los derribos sólo podrán autorizarse cuando el edificio «carezca de valor histórico, monumental o tipológico, o por cual- 
Hay varias sentencias que sí se refieren, expresamente resolviendo el caso, a la posibilidad de modificar las alineaciones de la estructura del conjunto histórico, eso sí, con la precisión de que se lleve a cabo a través del correspondiente plan especial.

\section{b, 2) Modificación de alineaciones en aplicación de legislación autonómica confirmada por el Tribunal Supremo}

Una vez aprobado un plan especial también la jurisprudencia admite la modificación de alineaciones en un conjunto histórico. El precedente judicial más claro de esta línea jurisprudencial se encuentra en la citada ${ }^{64}$ STS de 8-5-1989 (vigente sólo la LPHE pero aún no la LPCVa), que confirmó la aprobación de un plan especial de reforma interior en sector histórico-artístico de Valencia, que preveía abrir nuevas calles y plazas, al no afectar a la trama histórica, esto es a la que califica como "estructura fundamental o básica de la ciudad", sino a una estructura "secundaria".

Un supuesto de especial relevancia en el ámbito autonómico (por tratarse de una afección a zona singular de conjunto histórico), es el de la STSJ de Castilla y León de 5-5-2006 (rec. nº 659/2004) sobre la ampliación del edificio de la Casa Consistorial de Soria mediante una modificación puntual en el Plan

quier otra circunstancia», y se impone en todo caso el mantenimiento de la altura y el volumen preexistentes. Esta modificación respeta en sí misma considerada la limitación del artículo 21.3 sobre la excepcionalidad de la sustitución de inmuebles.

En la modificación núm. 9 se aclara, en sentido restrictivo, lo que puedan ser «renovaciones parciales», especificando que sólo lo serán «las pequeñas reparaciones o actuaciones en cualquier elemento de un edificio que puedan tener cabida en los conceptos de restauración, conservación y rehabilitación», lo que no contraría el artículo 21.3.

En la modificación núm. 12, que regula los aumentos de volumen en los edificios no monumentales con destino total a equipamientos de tipo comunitario, se limita el planificador a remitirse a lo que ya preveía antes respecto de las distintas Áreas (Cultural, Sanitaria, Asistencial, etc.) y a fijar el incremento en el Área Religiosa, que antes no tenía limitación expresa y que ahora se fija en un $15 \%$, que es lo que antes se autorizaba con carácter general para los equipamientos. Estas determinaciones no perjudican por sí mismas a la estructura urbana ni arquitectónica ni a las características generales del ambiente.

Todas las demás modificaciones (a excepción de las números 5, 6 y 15, a las que nos referíamos al principio) están relacionadas con éstas y no hay en ellas nada que infrinja los preceptos de la LPH" (FD 10. ${ }^{\circ}$.

Supra, aquí epígrafe a) anterior in fine. 
Especial de Reforma Interior y Protección del Conjunto Histórico de 27-10-2004 que se impugna por el Colegio de Arquitectos, y supone un cambio de alineaciones, una reordenación de espacios públicos colindantes a la Plaza Mayor y Palacio de la Audiencia, así como la supresión de la calle Teatro, alterando el trazado de la calle Pósito. El Tribunal resuelve primero la posible modificación del planeamiento general por el plan especial, y concluye que la supresión de una calle no es un sistema general ni afecta al modelo territorial del municipio, sino una dotación urbanística que no se puede considerar de ordenación general (FD 6..$^{\circ}$ ), límite que como se ha comentado se impone a los planes especiales por estar reservados al planeamiento general. Y en segundo lugar, el Tribunal se pronuncia sobre la posibilidad conforme a la legislación de las comunidades autónomas en ese caso, de modificación de alineaciones. Partiendo del tenor literal del art. 42, apdos. 1 (mantenimiento de la estructura urbana y arquitectónica) y 4 (prohibición de modificación de alineaciones y rasantes existentes, alteraciones de volumen, edificabilidad, parcelaciones, agregaciones o de la armonía del conjunto, salvo excepcionalmente "siempre que contribuyan a la conservación general del bien y estén comprendidas en la figura de planeamiento de protección”), de la Ley 12/2002 de Patrimonio Cultural de Castilla y León, el Tribunal resuelve que en tal actuación con alteración de alineaciones, no hay modificación de la estructura urbana y arquitectónica ${ }^{65}$.

En ese caso, no se entiende qué conservación del bien supone la eliminación de una calle que es trama histórica en un área especialmente relevante del Conjunto, como es la Plaza Mayor de Soria, que, como exponía el Colegio de Arquitectos, no es modelo de plaza castellana cerrada, al contrario, es y parece que ha sido siempre abierta, y eso la singulariza o al menos es lo que la caracterizaba precisamente, de forma que, a mi juicio, tal alteración no respeta el supuesto legal de la LPCGyL (ni en los mismos términos expuestos la LP$\mathrm{HE}$ ), sin que sea posible observar qué bien se produce al conjunto histórico con la supresión de una calle en plena confluencia con la Plaza Mayor, y en consecuencia, según mi criterio, esta modificación debió ser anulada.

“... no se aprecia que las modificaciones que se realizan produzcan una modificación en la estructura urbana y arquitectónica y de la silueta paisajística, así como de las características generales de su ambiente que afecten negativamente al bien de interés, sino todo lo contrario, se justifica el beneficio que a este bien se produce, sin que exista prueba que desvirtúe esta justificación, no produciéndose ningún cambio que afecte a la armonía del conjunto en sentido negativo, sino que contribuyen a la conservación del bien, al realizar el mismo" (FD 8. ${ }^{\circ}$, cursiva no original). 
También el Tribunal Supremo ha admitido la modificación de alineaciones una vez aprobado el plan especial de protección, y para ello pondera si tal alteración supone una afección a la estructura urbana o "trama histórica". En concreto son de gran relevancia al respecto las SSTS de 12-3-2008 (rec. ${ }^{\circ}$ $4054 / 2005)$ y 13-3-2008 (rec. $\mathrm{n}^{\circ}$ 4048/2005) en relación con la misma sentencia de instancia, que conocían de los recursos frente a la aprobación definitiva del Plan Especial y de Reforma Interior del Cabanyal-Canyamelar de Valencia por el Conseller de obras públicas y urbanismo valenciano y frente al informe previo de la Subsecretaría de la Consellería de Cultura sobre el proyecto del mencionado plan especial. Estas Sentencias se enmarcan en la regulación autonómica, en concreto el art. 39. 2 de la Ley del Patrimonio Cultural Valenciano $^{66}$, que establece expresamente posibilidades más amplias de alterar las alineaciones (como en el supuesto de la legislación de Castilla y León comentado supra), pero finalmente el Tribunal parece pronunciarse en términos más genéricos, y de hecho, se basa en la cita de la STS de 8-5-1989 mencionada, en la que se confirmaba un plan especial que articulaba nuevas plazas y calles en sector histórico-artístico por no afectar a la trama histórica o "fundamental", sino a la "secundaria".

Esta Sentencia de 13 de marzo, que reitera los pronunciamientos de la del día 12 anterior, resuelve diversas cuestiones trascendentales. Una vez que confirma la legalidad de la tramitación conjunta de plan especial de reforma y de protección (FD 2. ${ }^{\circ} \mathrm{g}$ ), afirma (FD 9..$^{\circ}$ ) que la alegación directa al art. 46 de la Constitución por el demandante sólo procedería en relación con la norma legal que lo desarrolla, de conformidad a lo establecido en el art. 53. 3 de la Constitución para los principios rectores, y al carecer de ésta la desestima. La Sentencia califica $e l$ informe previo de Cultura como acto de trámite inimpugnable en tanto no se incorpore a la resolución definitiva (FD 4. ${ }^{\circ}$ ). Por otro lado se plantea (dada la demanda) si la alteración de las alineaciones propuesta en el PEPRI puede constituir un supuesto de expolio, lo que le llevará a pronunciarse sobre la modificación de alineaciones. El Tribunal considera (FD $\left.12 .^{\circ}\right)$ que no puede afirmarse tal extremo, porque aunque las Administraciones públicas puedan ser sujetos activos de expolio, sin embargo tal tipo exige en primer lugar que los órganos competentes del Ministerio de Cultura hayan calificado el supuesto en esos términos previa la oportuna denuncia (datos ambos

"Se mantendrá la estructura urbana y arquitectónica del Conjunto y las características generales del medio ambiente y la silueta paisajística. No se permitirán modificaciones de alineaciones, alteraciones de la edificabilidad, parcelaciones ni agregaciones de inmuebles, salvo que contribuyan a la mejor conservación General del Conjunto". 
que en este caso no han llegado a producirse (o al menos el Tribunal no tenia noticia ${ }^{67}$ ), y en segundo lugar, tal infracción requeriría una actuación arbitraria o irracional, lo que tampoco aprecia el Tribunal dada la actuación conjunta de las Administraciones con competencias para ello, y la motivación y justificación de las modificaciones aprobadas. La motivación se va a revelar con especial transcendencia, y así, el Tribunal acepta los considerandos de la Sentencia de instancia (FJ. 6. ${ }^{\circ}$ ) que reproduce en su FD $3 .^{\circ}$ (apdo. e), mediante la justificación dada en los informes técnicos, esencialmente con base en modificación de mínimo imprescindible, la calidad ambiental, la habitabilidad y calidad del espacio del conjunto histórico, el diseño final de las nuevas alineaciones condicionado por su valor histórico, la integración en la ciudad del barrio, mantenimiento de la altura en las edificaciones $y$ de la unidad del barrio ${ }^{68}$. Esta motivación no constituye a mi juicio una inter-

Sobre la declaración estatal de expolio vid. la STS de 25-5-2009, y la actuación subsiguiente: Orden del Ministerio de Cultura 3631/2009, de 29 de diciembre, por la que se resuelve el procedimiento por expoliación del conjunto histórico del Cabanyal (BOE 8-1-2010); Decreto-Ley 1/2010, de 7 de enero, del Consell de la Generalitat Valenciana, de medidas de protección y restitución del conjunto histórico de la Ciudad de Valencia; y su impugnación mediante recurso de inconstitucionalidad 803/2010 ante el Tribunal Constitucional. Posteriormente Ley 2/2010 de revitalización del Conjunto Histórico de Valencia, también impugnada ante el TC.

Por su interés, en cuanto refiere la justificación necesaria en el plan especial para modificar alineaciones, se reproduce en extenso:

"La sentencia de instancia, en su Fundamento Jurídico Sexto, aborda la que Sala considera cuestión nuclear del litigio, que consiste en determinar si el PEPRI del "Cabanyal-Canyamelar" da cumplimiento al artículo 39.2.a) de la LPCVa por contribuir a la mejor conservación general del Conjunto.

De nuevo cita aquí la Sala de instancia el informe de la Conselleria de Cultura, que se sustenta a su vez en el dictamen del Arquitecto Sr. Cornelio, quien mantiene que el proyecto es respetuoso con la trama de los viarios, limitando al mínimo imprescindible la alteración de alineaciones introducida, por el hecho de que la prolongación proyectada se aparta de su traza natural, recta, para continuar en diagonal y su anchura se reduce a la mitad, alteraciones que dicho Arquitecto consideraría absolutamente incomprensibles e injustificables si no se hubiese tenido en cuenta el factor del medio urbano por el que atraviesa y de su valor histórico, el cual ha condicionado decisivamente el diseño final. Igualmente, frente al criterio mantenido por el Arquitecto Inspector de Patrimonio, que en su informe entiende la prolongación de la avenida Blasco Ibáñez como una "barrera" que partiría en dos los barrios afectados, el Sr. Cornelio atribuye esta apreciación a una "simplificadora visión del problema" y defiende la prolongación como "centro vertebrador de estos barrios", poniendo la misma en relación con el caso de la Gran Vía Marqués del Turia, a la que nadie podría atribuir, sin faltar a la verdad y el rigor, el papel de barrera en el Ensanche, sino más bien de todo lo contrario, como "elemento de orden principal y foco de actividad que, lejos de separar, une e identifica las piezas colindantes" que constituye el eje vertebrador del barrio del Ensanche. 
pretación razonable del supuesto de remodelación urbana (art. 21. 2 en relación con el apdo. $3 .^{\circ}$, primera frase, del mismo artículo, LPHE), de lo que constituye mejora y conservación del conjunto sin afectar a la trama histórica, como se comentará infra.

Se transcriben también en este apartado de la sentencia otros fragmentos del informe del Sr. Cornelio en los que se indica, entre otras cosas, que la no ejecución de esta apertura -la prolongación de la avenida Blasco Ibáñez- no garantizaría una revitalización sostenible de este núcleo y que, por el contrario, la apertura del Paseo al Mar mejorará muy sensiblemente la escala urbana, la habitabilidad y las condiciones medio-ambientales del trazado urbano actual, una densa y mal aireada trama cuyo valor histórico o singularidad no justifica su preservación integral a costa de su viabilidad futura y de su calidad ambiental; por lo que el Arquitecto informante considera que la remodelación limitada de alineaciones que representa la apertura proyectada del Paseo al Mar está más que justificada por la mejora que en la habitabilidady calidades del espacio fisico urbano representa esta avenida.

Y después de reseñar lo anterior -lo que hemos recogido no es sino una síntesis del Fundamento Jurídico Sexto de la sentencia- la Sala de instancia hace la siguiente valoración:

“(...) Pues bien, estas razones se comparten por la Sala y no han sido desvirtuadas convenientemente por la actora, que admite no obstante la degradación del barrio si bien lo achaca al olvido histórico a que ha sido sometido por las Administraciones Publicas y al hecho de que el Plan General de 1988 decidiera diferir el desarrollo planificador del barrio. En consecuencia, no solo se trata de facilitar la conexión de Valencia con el Mar, el propio nombre original de prolongación del Paseo al Mar, como se denominó en su día a la calle Blasco Ibáñez, delata esta finalidad, por otra parte legítima, y que por sí misma pudiera justificar el sacrificio particular de determinados derechos, sino igualmente de lograr la mejora del barrio del Cabanyal-Cañamelar, facilitando su integración en la Ciudad y siendo respetuoso con la identidad del conjunto del barrio, al prever el PEPRI una penetración en el mismo blanda, mediante una avenida-bulevar de 48 metros de ancho, alterando la línea recta lógica, al objeto de evitar los menores perjuicios al citado Barrio, respetando las alineaciones en sentido horizontal de las calles con las que cruza y manteniendo una altura de edificación en sus márgenes de 5 alturas, moderadas en relación con la anchura de la calle, que contrastan con las 20 que de media existen en la Avenida que se prolonga, de tal suerte que no se rompe la unidad del barrio objeto de protección que será siempre reconocible por dichas circunstancias.

Esta interpretación del artículo 39.2 de la Ley 4/1998, aun cuando no referida a dicho precepto, tiene respaldo jurisprudencial en la sentencia del Tribunal Supremo de 8 de mayo de 1989, recaída precisamente en un Plan Especial que afectaba a una trama histórico-Artística del suelo urbano de Valencia, en concreto al Barrio de Velluters, y dice en su fundamento jurídico tercero que: "Establecido lo anterior y puesto en relación con la legalidad urbanística vigente en Valencia y su comarca es patente que la apertura de nuevas calles y de plazas que se prevén en el Plan Especial de Reforma denominado dels Velluters o del Pilar no modifica la estructura fundamental del Plan General, ni rompe la coherencia de éste. Porque, tal y como requiere el Plan General, respeta la trama histórico-artística del suelo a que se refiere e incluso la recobra y la realza mediante la demolición de inmuebles que [han] alcanzado un grado de deterioro irreversible". Esto es, la apertura de nuevas calles y plazas no supone en si misma una incompatibilidad con la trama histórico-artística". (FD 2. ${ }^{\circ}$ STS 13-3-2008 citada, cursiva no original). 
Y finalmente el Tribunal vuelve a plantearse (FD 13. $)$ en concreto si hay vulneración de la norma autonómica referida sobre prohibición de modificación de alineaciones salvo que contribuyan a la mejor conservación del conjunto. El demandante sostenía (FD 13. ${ }^{\circ}$ ) que la Sentencia de instancia infringía jurisprudencia del Supremo que cita (SSTS 5-3-1999 y 29-1-200069) y el Tribunal afirma que tal doctrina se refiere sólo a la norma estatal y no a la autonómica - lo que parece inquietante si la solución en el supuesto de la norma estatal pudiera ser distinta dado que parece poder admitir la competencia de las Comunidades sobre la materia-, pero, además, añade el Tribunal de forma lacónica, que tampoco hay contradicción de tal doctrina con la solución adoptada por la Sentencia de instancia. En todo caso el Tribunal concluye aludiendo no sólo a la regulación autonómica sino también al Convenio Europeo del Paisaje de 20 de octubre de 2000, en una solución ponderada entre la "exacerbada protección y la conservación imprescindible", en la solución de lo que deba considerarse "contribución a la mejor conservación del conjunto" en los términos del art. 39. 2 de la Ley Valenciana ${ }^{70}$. Las referencias de la Sentencia al

Como se ha comentado sólo la STS 5-3-1999 parece que aplica literalmente el art. 21. 3 LPHE; posiblemente la cita supuesta por el demandante de la STS 29-1-2000 sea un error, y se refiera a la STS 29-1-2002, aquí citada supra II, pero ésta trata de una alteración de volumen, edificabilidad y superficie de ocupación (parece que además sin alteración de alineación) sin plan especial (art. 20. 3 LPHE), por lo que no resulta aplicable al caso de enjuiciamiento de alteración de alineaciones mediante plan especial (art. 21 LPHE).

"Al margen de tratarse de una jurisprudencia relacionada con la norma estatal que se cita - y no con la norma autonómica- su análisis conduce a la conclusión de no resultar su doctrina contradictoria con la decisión adoptada por la Sala de instancia al interpretar, en forma correcta, la norma autonómica que, sin duda, posibilita la modificación de alineaciones - así como otras actuaciones que la norma cita, tales como las alteraciones de la edificabilidad, las parcelaciones y las agregaciones de inmuebles-, siempre y cuando las mismas "contribuyan a la mejor conservación general del Conjunto", que es justamente la conclusión a la que llega la sentencia de instancia en relación con el PEPRI impugnado alcanzado una interpretación equidistante entre un reduccionismo exacerbado y la imprescindible conservación y mejora futura del patrimonio histórico.

Tal actuación urbanística y la decisión jurisdiccional que la avala se sitúan en el actual ámbito del Convenio Europeo del Paisaje (núm. 176 del Consejo de Europa), hecho en Florencia el 20 de octubre de 2000 y recientemente ratificado por España mediante Instrumento de Ratificación de 6 de noviembre de 2007, publicado en el BOE núm. 31, de 5 de febrero de 2008, y en el que los Estados Miembros del Consejo de Europa reconocen su preocupación "por alcanzar un desarrollo sostenible basado en una relación equilibrada y armoniosa entre las necesidades sociales, la economía y el medio ambiente", ya que, tras reconocer todos los beneficios que la conservación del paisaje implica, sin embargo, toman nota "de que la evolución de las técnicas de producción 
Convenio Europeo del Paisaje y la solución ponderada del planeamiento a la que se refiere, parecen relacionar esta argumentación con la de la STS 29-3-2004, citada supra.

Estas dos sentencias plantean, de un lado, la aplicación de la legislación de la propia Comunidad, y, de otro, su interpretación y en su caso validez en el marco de la legislación estatal, lo que no se plantea o no discute el Tribunal. La primera cuestión, según mi criterio, se resuelve confusamente en las dos sentencias citadas, dado que parece evidente la modificación de la estructura urbana, ya que no se trata de cambios puntuales sino de una seria afección a la trama urbana.

En definitiva, sobre la posible duda en la interpretación de los apartados 2 y 3 del art. 21 LPHE, se puede concluir, según mi criterio, que la Ley determina como regla general la conservación de la estructura y arquitectónica (art. 21. 3, primera frase, LPHE), lo que supone que en un conjunto con plan especial aprobado sólo excepcionalmente serán admisibles: el supuesto de sustitución de inmuebles si contribuye a la conservación general del carácter del conjunto y en este caso conservando las alineaciones (art. 21. 3, segunda frase, LPHE); y el supuesto de remodelaciones urbanas, para una mejora de la relación con el entorno territorial urbano o las que eviten usos degradantes del propio conjunto (art. 21. 2 LPHE). Este supuesto implica asumir sólo la posible modificación de alineaciones justificadas en remodelaciones urbanas ("sólo en caso de que impliquen una mejora de sus relaciones con el entorno territorial urbano o eviten los usos degradantes para el propio Conjunto") previstas en el plan especial, que respeten la estructura urbana (trama histórica, art. 21. 3, primera frase, LPHE) y no las que pretendieran derivarse de puntuales sustituciones de inmuebles (aunque estuvieran en plan). Se requeriría, entonces, un plan especial que hubiera proyectado y justificado una remodelación urbana para la mejora de conservación del conjunto que hubiera previsto modificaciones puntuales de

agrícola, forestal, industrial y minera, así como en materia de ordenación del territorio y urbanística, transporte, infraestructura, turismo y ocio y, a nivel mas general, los cambios en la economía mundial están acelerando en muchos casos la transformación de los paisajes". Esto es, la actuación urbanística que nos ocupa se sitúa en el marco de una política que combina la protección de los aspectos más significativos y característicos del Conjunto Histórico Cabanyal-Canyamelar con la decisión - adoptada en el PGOU y calificada de objetivo irrenunciable del mismo- de conseguir abrir la ciudad al mar; decisión, objetivamente compartida con otras muchas ciudades que con sus nuevos paseos marítimos - de manifiesta aceptación ciudadana- terminan con otras concepciones históricas de cerrar la ciudad al mar y construirla de espaldas a ella" (FD 13. ${ }^{\circ}$ STS 13-3-2008, cursiva no original). 
alineaciones que no afectaran a la estructura urbana. Y la mejora de la conservación del conjunto se deberá acreditar justificando, al menos de momento, que se trate de modificaciones de mínimo imprescindible, por la calidad ambiental y habitabilidad del conjunto, el diseño final de las nuevas alineaciones condicionado por su valor histórico, la integración de la ciudad en el barrio, y el mantenimiento de la altura de las edificaciones -en este caso- y de la unidad del barrio.

En este contexto se puede interpretar la regulación de las Comunidades que no han especificado más que la legislación estatal, y las que lo han concretado en este sentido, sirviendo como apoyo a esta argumentación los pronunciamientos de las SSTS de 8-5-1989 y de 12 y 13 de marzo de 2008, citadas. Sólo la STS 5-3-1999 parece determinar la aplicación extensiva del art. 21. 3, segunda frase, LPHE también a las remodelaciones urbanas (del art. 21, apdo. 2 y apdo. 3 en su primera frase). Además, en sentido contrario otra STS posterior de 2-2-2000, citada, negaba la posibilidad de modificar alineaciones en conjuntos mientras no existiera plan especial y ello sólo con base en la LPHE (FD 5. ${ }^{\circ}$, pafo $3^{\circ}$, transcrito supra), obiter dictum que a contrario permite confirmar esta interpretación que aquí se propone.

A mi juicio no resulta necesario ponderar con condiciones extrañas a la Ley con base en conceptos metajurídicos, en términos de la STS de 29-3-2004, citada, sino con base en los objetivos de protección de la propia Ley, los de mantenimiento a ultranza de las alineaciones, de un lado, o la conservación del conjunto (que en su caso incluye su mejora y modificación de alineaciones sin afectar a su estructura urbana básica o trama histórica), de otro, como bien han matizado algunas normas de comunidades autónomas, y constituyen la base del pronunciamiento de las SSTS de 12 y 13 de marzo de 2008 (FD 13. ${ }^{\circ}$ ), marco jurisprudencial y legal, que vislumbra una interpretación acorde de ambas determinaciones. Esta doctrina judicial, al margen de la solución del caso concreto que se comentará infra si bien se realiza en interpretación de normas de las Comunidades citadas, resulta a mi juicio racionalmente contextualizada en el el art. 21. 2 LPHE (respeto a la estructura urbana y posibles reformas que no le afecten y supongan mejora del conjunto), precepto que necesariamente también se aplica (se trata de legislación del Estado en ámbito de sus competencias de cultura y expolio, como recuerda la STG 17/1991, 31 de enero sobre la $\mathrm{LPHE}^{71}$ ) en las demás comunidades autónomas que sí han

FD $3 .^{\circ}$, en el que confirma la competencia legislativa del Estado para aprobar una definición unitaria de este patrimonio cultural como tratamiento general en la materia. 
especificado expresamente tales mejoras de la conservación del conjunto $\mathrm{BIC}$ a través de modificación de alineaciones excepcionales (supuestos de remodelación urbana). Esta interpretación (que estaría avalada además por las SSTS 8-5-1989 y 2-2-2000, citadas, en aplicación de legislación estatal) es más coherente con la determinación legal de graduar la protección de las áreas de los conjuntos (y de sus entornos se entiende) ${ }^{72}$ y con la jurisprudencia que atiende en el seno del conjunto a los grados de protección delimitados en el plan especial de protección.

La motivación de la remodelación urbana que ampare en su caso modificación de alineaciones adquiere entonces un carácter primordial y se revela crucial, así la argumentación señalada en la jurisprudencia referida supra (STS 13-3-2008, STS 29-3-2004). Se disiente así de la aplicación general del pronunciamiento de la STS 5-3-1999, citada, ya que las normas permiten expresamente en el conjunto las remodelaciones urbanas que sin afectar a su estructura básica (trama histórica) impliquen una mejora del entorno territorial o urbano y contribuyan a la conservación general del conjunto. En esta motivación será obligado considerar los aspectos referidos en la citada jurisprudencia: con gran prudencia, se puede partir de la discrecionalidad (competencia) para decidir mantener las alineaciones tradicionales, que exponen las SSTS 12-5-1992 y 8-4-1989, citadas, y a contrario, por tanto, en los supuestos legales, competencia para decidir modificarlas; y necesidad de que, al menos, se motive en informes técnicos, así en la STS 13-3-2008 en argumentación transcrita, dada en los informes técnicos, esencialmente con base en modificación de mínimo imprescindible, la calidad ambiental, la habitabilidad y calidad el espacio del conjunto histórico, el diseño final de las nuevas alineaciones condicionado por su valor histórico, la integración en la ciudad del barrio, mantenimiento de la altura en las edificaciones y mantenimiento de la unidad del barrio. Con la duda en ese caso de la Sentencia de 13-3-2008, de si se respeta realmente la estructura urbana del Conjunto, que se comentará infra.

Además como orientación para la motivación del oportuno plan especial de protección, se debería tener en consideración la Carta Internacional para la conservación de ciudades históricas y áreas urbanas históricas ("Carta de Washington", 1987), del ICOMOS (Consejo Internacional de Monumentos y de Lugares de

Art. 21. 1 LPHE y legislación en el mismo sentido de las comunidades autónomas. 
Interés Artístico e Histórico) que ofrece diversos criterios orientadores: conservación de la forma urbana definida por la trama y el parcelario; relación entre la población o área urbana y su entorno -epígrafe 2, a-; cuidado de las infraestructuras y servicios públicos -epígrafe 8-; la mejora del "hábitat" como objetivo básico de la conservación -9-; respeto al parcelario en el caso de ser necesaria la transformación de edificios -10-; conservar el aspecto y forma de los edificios, estructura, volumen, estilo-2,b-; en todo caso con planes precedidos de estudios y análisis multidisciplinares, arqueológicos, históricos, arquitectónicos, técnicos, sociológicos y económicos -5-; tratando de lograr una relación armónica entre el área urbana histórica y el conjunto de la población -5-; mediante intervenciones con prudencia, método y rigor, en atención a cada caso particular -epígrafe 4-); todo ello de conformidad con lo exigido en su epígrafe $6^{73}$.

Por otra parte, las cautelas del art. 21.3, segunda frase, LPHE, deben quedar de lado en el caso de entornos de conjuntos históricos, teniendo en cuenta que el precepto se refiere en concreto al conjunto propiamente dicho y no a su entorno, que será objeto de protección pero en virtud de lo que establezca el plan especial, de acuerdo con la finalidad de protección del mismo, la adecuada visualización del bien o de los espacios relacionados históricamente con él.

Si además concurriera declaración como ciudad patrimonio de la humanidad, respecto a la zona declarada con valor universal excepcional o su zona de amortiguamiento, se debería estudiar y en su caso acreditar (motivación adecuada) en el plan especial de protección, que su zona de amortiguamiento no va a deteriorar las zonas declaradas (valor universal excepcional), en atención a la Convención para la protección del Patrimonio mundial cultural y natural (París, 21-11-1972, esencialmente arts. 4,5 y 6 , genéricos, en concreto art. 6.3 , asegurar que no causa daño directo o indirecto al patrimonio), y sus Directrices prácticas para la aplicación de la Convención del Patrimonio Mundial (conforme a revisión actualizada de 2008), elaboradas por el Comité del Patrimonio Mundial, en concreto directrices 96-102, para la zona de amortiguamiento, directrices 103-107, sistemas de gestión y uso (108-119), sobre protección de la integridad de la zona declarada con valor universal excepcional, sin que los cambios le afecten negativamente - directrices 98 y 119-, y que en ningún caso supongan modificaciones que afecten a la zona declarada con valor universal excepcional, directrices 169 ss, que

“6. En caso de que se careciera de un plan de conservación o éste estuviera en estudio, antes de la adopción del plan todas las actividades necesarias para la conservación deberán ajustarse a los principios y métodos de la presente Carta y de la de Venecia." 
establecen la necesidad de comunicación al Estado, y que por supuesto no supongan en ningún caso una de las situaciones de peligro referidas en las directrices 177 ss.

\section{c) La coordinación de competencias municipales y de la comuni- dad autónoma o isla en la aprobación de los planes especiales}

La aprobación de los planes especiales ${ }^{74}$ obligará a una articulación de las competencias urbanísticas, de patrimonio cultural y de medio ambiente (evaluación ambiental estratégica o, en su caso, de impacto ambiental).

La aplicación de la legislación urbanística supletoria del Estado, RPU, en defecto de regulación más precisa, o la equivalente de las Comunidades derivará, en su caso, en la atención al procedimiento de aprobación bifásico, por el Ayuntamiento y la comisión provincial de urbanismo. Así el contenido de los planes especiales ${ }^{75}$ se determina en el art. 72.2 apdos. $\underline{\text { c }}$ (reforma interior) y $\underline{\mathrm{d}}$ (protección de conjuntos), RPU. La elaboración del plan especial se realizará por el municipio (art. 146 RPU), al igual que la aprobación inicial y provisional (art. 147. apdos. 1 y 2, RPU respectivamente), y la aprobación definitiva, conforme a las reglas de los planes parciales, arts. 147. 3 y 148, RPU, que remiten al art. 138. 3 RPU (Consejería de la comunidad autónoma si son capitales de provincia o superiores a 50.000; a la comisión provincial en el resto de los casos).

En este procedimiento de aprobación, además, será necesario el previo informe del órgano con competencias en patrimonio histórico (el art. 78. 4 RPU insiste en el mismo trámite del art. 20.1 LPHE), que por tratarse de conjunto histórico declarado, deberá ser favorable (art. 20. 1 LPHE) para que pueda ser

Otros estudios detallados sobre los planes especiales, su elaboración y contenido J. M. ALEGRE ÁVILA, Evolución y régimen jurídico del patrimonio histórico, 1994, II, pp. 129 ss., y "La ordenación urbanística de los centros históricos", en Urbanismo y patrimonio histórico, 1999, pp. 185-195, y pp. 127-130; R. DE VICENTE DOMINGO: Los planes especiales de ordenación urbana, 2007, estudio que aunque formalmente abarca el Derecho valenciano, es generalizable esencialmente al resto del ordenamiento español dada su similitud. Sobre los planes especiales en la legislación vasca, vid. J. M. ABAD LICERAS, La protección del patrimonio inmobiliario histórico en el ordenamiento jurídico vasco, 2002, pp. 325-332; y J. G. GÓMEZ MELERO, La protección del patrimonio histórico-artístico inmobiliario de Castilla-La Mancha a través de las técnicas urbanísticas, 2006, pp. 131 ss.

A. MENÉNDEZ REXACH: "Los planes especiales de protección del patrimonio histórico" en Urbanismo y patrimonio histórico, 1999, pp. 185-195, incluye un esquema tipo de Ordenanzas de los planes especiales de protección. 
aprobado por el órgano con competencias urbanísticas. Por tanto, esa intervención a través del informe favorable previo a la aprobación definitiva será determinante para ésta. En atención además a la jurisprudencia del Tribunal Supremo, la competencia sobre patrimonio histórico podrá ser considerada por el órgano autonómico en materia de urbanismo que apruebe definitivamente el plan especial siempre que, de acuerdo con esa jurisprudencia, se trate de modificaciones (las introducidas en la aprobación definitiva) justificadas por la irrazonabilidad de la propuesta municipal (la motivación municipal del planeamiento será de nuevo crucial para en este caso acreditar la razonabilidad de la decisión) o que afecten al modelo territorial supralocal (en el que se incluye la protección del patrimonio cultural y natural). En este sentido se puede destacar el pronunciamiento de la STSJ de Cataluña de 18-10-1996 (rec. n ${ }^{\circ}$ 1306/1994) que además de recordar esa jurisprudencia del Tribunal Supremo ${ }^{76}$, también descarta algunas modificaciones pretendidas en la aprobación

“... se exige traer a colación la evolución jurisprudencial recayente en materia de autonomía municipal y competencias de la administración autonómica a la luz de los nuevos principios organizativos introducidos por nuestra Constitución - artículos 137 y 140-. A estos efectos, deberá recordarse que «la Constitución atribuye a los municipios autonomía "para la gestión de sus respectivos intereses". Esta es su finalidad u objeto y por lo tanto la base para una definición positiva y negativa de la autonomía: a) positivamente, la autonomía municipal significa un derecho de la comunidad local a la participación, a través de órganos propios en el gobierno y administración de cuantos asuntos le atañen graduándose la intensidad de esa participación en función de la relación de los intereses locales y supralocales dentro de tales materias o asuntos; b) negativamente, es de indicar, que la autonomía no se garantiza por la Constitución, como es obvio, para incidir de forma negativa sobre los intereses generales de la nación o en otros intereses generales distintos de los propios de la entidad local». Además no puede pasarse por alto la acomodación que ha sufrido el artículo 41 del Texto Refundido de 1976 con la diferenciación de aspectos reglados y discrecionales y, en ambos supuestos, por razón de intereses locales o supralocales -Sentencias del Tribunal Supremo Sala 3. ${ }^{a}$ Sección 6. ${ }^{\text {a de }} 13$ julio 1990 (RJ 1990\6034), de 22 diciembre 1990 (RJ 1990\10183), de 30 enero 1991 (RJ 1991 \614) y de 12 febrero 1991 (RJ 1991 \948), y de la Sección 5. a de 25 abril 1991 (RJ 1991\3430), de 20 noviembre 1991 (RJ 1991\9156), de 24 abril 1992 (RJ 1992\3986), de 18 mayo 1992 (RJ 1992\4219), de 22 septiembre 1992 (RJ 1992\6974), de 14 junio 1993 (RJ 1993\5023) y de 21 febrero 1994 (RJ 1994\1455), entre otras- .

A ese respecto reiterando las premisas de tal doctrina jurisprudencial interesa dejar sentadas las siguientes apreciaciones:

«... una acomodación del artículo 41 del Texto Refundido al principio constitucional de la autonomía municipal ha de concretar la extensión del control de la Comunidad Autónoma en el momento de la aprobación definitiva del planeamiento en los siguientes términos:

A) Aspectos reglados del plan: control pleno de la Comunidad con una matización para el supuesto de que entren en juego conceptos jurídicos indeterminados - es bien sabido que éstos admiten una única solución justa y que por tanto integran criterios reglados-- a) Si la determina- 
definitiva sin cobertura en el modelo territorial supralocal: en ese caso, la imposición de un cambio en las cubiertas (plana y no inclinada) en un plan especial de conjunto histórico no afectaría al modelo territorial supralocal ${ }^{77}$.

Finalmente, en la elaboración se atenderá a la regulación sobre evaluación ambiental estratégica que determina la intervención del órgano ambiental de la comunidad autónoma, de conformidad con los arts. 7 a 15 de la Ley 9/2006,

ción del planeamiento que se contempla no incide en aspectos de interés supralocal, el margen de apreciación que tales conceptos implica corresponde a la Administración municipal. b) Si el punto ordenado por el plan afecta a intereses superiores ese margen de apreciación se atribuye a la Comunidad. B) Aspectos discrecionales.

También aquí es necesaria aquella subdistinción. a) Determinaciones del plan que no inciden en materias de interés autonómico. Dado que aquí el plan traza el entorno físico de una convivencia puramente local y sin trascendencia para intereses superiores ha de calificarse como norma estrictamente municipal y por tanto: a') Serán, sí, viables los controles tendentes a evitar la vulneración de las exigencias del principio de interdicción de la arbitrariedad de los poderes públicos tal como en este terreno las viene concretando la jurisprudencia-Sentencias de 1 y 15 diciembre 1986 (RJ 1987\417 y RJ 1987\1139), de 19 mayo y 11 julio 1987 (RJ 1987\5812 y RJ 1987 6877), de 18 julio 1988 (RJ 1988\5914), de 23 enero y de 17 junio 1989 (RJ 1989 427 y RJ 1989\4730), de 20 marzo, de 30 abril y de 4 mayo 1990 (RJ 1990\2246 y RJ 1990\3799) y de 11 febrero, de 27 marzo y de 2 abril 1991 (RJ 1991\1982, RJ 1991\2226 y RJ 1991\3278), etc- ${ }^{-}$b') No serán en cambio admisibles revisiones de pura oportunidad; en este terreno ha de prevalecer el modelo físico que dibuja el Municipio con la legitimación democrática de que le dota la participación ciudadana que se produce en el curso del procedimiento. b) Determinaciones del planeamiento que tienen conexión con algún aspecto de un modelo territorial superior: además de lo ya dicho antes en el apartado a'), aquí y dado que "en la relación entre el interés local y el supralocal es claramente predominante este último -Sentencia del Tribunal Constitucional 170/1989 (RTC 1989\170)- resulta admisible un control de oportunidad en el que prevalece la apreciación autonómica"» (FD 5. $\left.{ }^{\circ}\right)$.

Y en relación a la imposición de la cubierta en ese plan especial, en su FD $6 .^{\circ}$ concluye:

"Pues bien, detectándose que la postura de la Administración Municipal se decanta por una cubierta inclinada de teja a tres aguas y la de la Administración Autonómica por una cubierta de terraza plana y atendido que nos hallamos ante una figura de planeamiento especial de la naturaleza indicada, que modifica en parte la anterior, no se llega a alcanzar cuáles son las razones o intereses supralocales que puedan estimarse ni que la decisión adoptada por la Administración Municipal sea arbitraria. En definitiva, el convencimiento recae en que nos hallamos en materia de discrecionalidad administrativa afectante a meros intereses locales lo que obliga a estimar que prevalezca la decisión municipal y que determina, en aplicación de la doctrina jurisprudencial expuesta el éxito de la pretensión actuada por la parte actora en el presente proceso conforme se establecerá en la parte dispositiva." 
de 28 de abril, en cuanto se considere plan que afecta significativamente al medio ambiente (de acuerdo con el art. 3 Ley 9/2006), lo que necesariamente remite a la concreción por la regulación de evaluación estratégica de las Comunidades, al carecer de una determinación a este respecto en la legislación de patrimonio histórico referida en su caso a actividades sometidas a evaluación de impacto ambiental pero que en general aún no previeron la evaluación ambiental estratégica ${ }^{78}$. De acuerdo con esta legislación básica y las normas adicionales de protección de las Comunidades en materia de evaluación ambiental estratégica, el Ayuntamiento redactará el informe de sostenibilidad ambiental (que incluirá la protección del patrimonio histórico de acuerdo con el art. 9 Ley 9/2006), y, tras una fase de consultas, se redactará la memoria ambiental por el órgano ambiental que contendrá las determinaciones que deban incorporarse a la propuesta del plan por el Ayuntamiento antes de su aprobación (arts. 7 ss Ley 9/2006). Será necesario articular el informe de cultura y el procedimiento de evaluación del plan especial. Salvo mejor criterio especificado en la legislación de las comunidades autónomas sobre evaluación ambiental estratégica, a falta de otra precisión en la legislación de patrimonio histórico, considero que es en la fase de consultas (art. 10 Ley 9/2006) en la que debe integrarse el informe favorable del órgano en materia de cultura.

En consecuencia, en la aprobación del plan especial de protección se debe considerar de un lado la competencia urbanística de aprobación definitiva, que puede incluir determinaciones en materia de patrimonio histórico siempre que afecten al modelo territorial supralocal o sean por motivos de irrazonabilidad (en el documento presentado por el Municipio), con base en los arts. 147, 148 y 138. 3 RPU (o equivalente legislación urbanística de las comunidades autónomas); de otro, la competencia de la Comunidad o Isla en materia de patrimonio histórico ejercida a través del informe (favorable necesariamente) previo, de conformidad con el art. 20.1 LPHE; y la del órgano con competencias en medio ambiente natural, que aprobará la memoria ambiental con las determinaciones que debe incorporar el Ayuntamiento en la propuesta del plan (arts. 7 ss Ley 9/2006).

Tímidamente, se alude a la evaluación de los planes en el art. 21. 2 LPCMur, art. 32.1 LPCNa y art. 30 LPCGyL, pero sin que se hayan precisado los problemas de articulación de las competencias de patrimonio cultural y de medio ambiente que se suscitan. 


\section{d) La articulación de competencias en los supuestos de sustitución de inmuebles una vez aprobado el plan especial del conjunto; la au- torización en zonas arqueológicas o paleontológicas, monumentos y sus entornos}

Una vez aprobado el plan especial, éste habrá incorporado las determinaciones sobre sustitución de alineaciones o de inmuebles, y serán controladas, prima facie, sólo por el Ayuntamiento (art. 20. 4 LPHE), salvo los supuestos de monumentos, zonas arqueológicas o paleontológicas y sus entornos (sólo de los de estas áreas, no de los conjuntos evidentemente). Alguna duda puede suscitar si tal precepto subsume la autorización requerida expresamente para el caso de sustitución de inmuebles o ruina (art. 24. 2 LPHE y preceptos correlativos de las comunidades autónomas $\left.{ }^{79}\right)$.

En la jurisprudencia ha habido numerosos $\operatorname{supuestos}^{80}$ en los que se declara conforme a Derecho el ejercicio de la competencia de las comunidades

En algunas Comunidades la interpretación puede requerir más especificidades: como ejemplo, en las Islas Baleares, el punto de partida es la interpretación conjunta de los arts. 37 y 42 LPHIB, en los que de un lado se establece la necesidad de autorización de la Comisión Insular de Patrimonio Histórico de cualesquiera "obras o intervenciones en un conjunto" mientras no se apruebe plan especial y salvo los supuestos de monumentos, zonas arqueológicas o paleontológicas y sus entornos (art. 37, apdos. 2 y 3 LPHIB) y de otro la autorización de la misma para la demolición de un "inmueble de interés cultural o catalogado" (art. 42. 2 LPHIB). La LPHIB se ha de referir necesariamente a los declarados o catalogados conforme a los procedimientos que ella misma establece, excluyéndose en todo caso otras edificaciones objeto de declaraciones o catalogaciones externas a la misma. Como se ha señalado, si no hay plan especial cualquier intervención en el conjunto debería requerir autorización adicional, y en los mismos términos se exigiría tal autorización fuera del conjunto, para la demolición de cualquier inmueble de interés cultural o catalogado conforme a la LPHIB; si se ha aprobado tal plan especial, sólo precisan autorización las obras en monumentos o jardines históricos o en zonas paleontológicas o arqueológicas o sus entornos, aunque coincidan con el conjunto, lo que necesariamente excluye también los supuestos de ruina en conjuntos y sus entornos, como especifica la STSJ de Castilla y León de 1-10-1999, que se expone infra. El art. 38. 3 LPHAnd, de forma lógica, ha englobado expresamente los supuestos de ruina en los de las autorizaciones en conjuntos históricos tras la aprobación de plan especial, al margen de que en esta Ley exista un régimen peculiar de competencias delegadas, Ley cuyas peculiaridades han sido estudiadas por C. BARRERO RODRÍGUEZ, "Las innovaciones de la Ley 14/2007, de 26 de noviembre, del Patrimonio Histórico de Andalucía en la ordenación urbanística de los conjuntos históricos" en la Revista Andaluza de Administración Pública, pp. 73-111, en concreto sobre la ruina, pp. 101 ss.

Citados aquí supra II c. 
autónomas o insular, en tanto no hubiera plan especial. Se ha transcrito además la STS 18-12-1997 (aquí supra) en la que se aludía (FD 3.º a la competencia local con base en el art. 20 LPHE una vez aprobado el plan especial, si bien es cierto que en ese caso, como se comentó, en el relato de hechos no está claro si había aprobado plan especial.

Existe un único pronunciamiento de un Tribunal Superior de Justicia que, en el supuesto específico de sustitución de inmuebles en conjunto con plan especial aprobado, anula la obligación de conservar impuesta en la autorización autonómica tras la declaración de ruina municipal: la STSJ de Castilla y León de fecha 1-10 1999 (rec. n 101/1998). El Tribunal, una vez que confirma la impugnabilidad del informe que recoge la resolución autonómica al considerar que se trataría en su caso de acto de trámite que impide continuar con el procedimiento o produce indefensión (FD 3. ${ }^{\circ}$ ), anula la resolución de la comunidad autónoma al estimar que carece de competencia una vez aprobado el plan especial ${ }^{81}$.

La determinación que impone una única autorización directa municipal, una vez aprobado el plan especial de protección del conjunto, debe englobar a la exigencia de autorización de la Administración cultural en los supuestos de ruina en el conjunto histórico, salvo que a su vez se refiera a jardín o monumento históricos, o zona arqueológica o paleontológica o su entorno (de esos BIC, no de entorno del conjunto), en cuyo caso sí sería necesaria la autorización (art. 20.4 y 22.1 LPHE). La ley ha establecido un mecanismo de coordinación

"Removido el anterior obstáculo resta examinar si la Comisión Territorial de Patrimonio Cultural de Ávila tenía o no competencia para autorizar o no esa demolición, y así el recurrente se basa en que la existencia de un Plan Especial de protección del área afectada determina que sea aplicable el núm. 4 del artículo 20 de la Ley 16/1985 y por tanto los Ayuntamientos sean directamente competentes para autorizar directamente las obras que desarrollen el Planeamiento aprobado y afecten únicamente a los inmuebles que no sean Monumentos ni Jardines Históricos ni a los demás a los que se refiere dicho artículo.

El citado Plan Especial del Conjunto Histórico de Ávila vigente desde el 3 de junio de 1988, existe tal y como ha sido remitido por el Ayuntamiento en la prueba acordada para mejor proveer, y por lo tanto en principio sí se aplicaría el artículo 20.3 siendo directamente competente el Ayuntamiento, ya que como consta al folio 94 de la Comisión Territorial de Patrimonio Cultural de la Junta de Castilla y León ésta basaba precisamente su competencia en el artículo 20.3 dado que como vemos no es aplicable, no podría admitirse que el Ayuntamiento carezca de competencia en este supuesto de acuerdo con las normas que el mismo Ayuntamiento ha remitido si procediere todo ello, procediendo por todo ello la estimación del presente recurso." (FD $\left.4 .{ }^{\circ}\right)$. 
(la aprobación previo informe favorable del plan especial), y posterior control mediante una única autorización municipal (y notificación a la Comunidad o Isla) que simplifica el procedimiento.

En definitiva, la previsión del art. 24. 2 LPHE o en el mismo sentido la correlativa legislación de las Comunidades, sólo se aplicará en el ámbito de los conjuntos, mientras no tengan plan especial de protección aprobado, o en todo caso, cuando se trate de monumentos, o zonas arqueológicas o paleontológicas o sus entornos (arts. 20.4 y 22. 1 LPHE). En la regulación estatal hay que completar la referencia en el art. 20. 4 a los monumentos y jardines, con la de las zonas arqueológicas, y paleontológicas, del art. 22. 1 LPHE, aun en el supuesto de que tales zonas se enclaven en un conjunto histórico, supuesto que no articuló adecuadamente el legislador estatal, pero que con base en el art. 22. 1 LPHE requiere en todo caso autorización, como sí han detallado las comunidades autónomas ${ }^{82}$.

Parece insistir en este criterio de inexigibilidad de autorización de la comunidad autónoma en conjunto con plan especial aprobado, la STSJ de Castilla y León de fecha 12-11-2004 (rec. no 3128/1998), que en un caso de impugnación del Acuerdo municipal que aprueba el estudio de detalle y la licencia de obras en conjunto histórico (construcción por la Universidad de aparcamiento en conjunto histórico de Salamanca) estima que no requieren autorización de la Comunidad en cuanto no se trata de un bien declarado (singularmente se entiende) BIC con plan especial aprobado ni en su entorno ${ }^{83}$, aun-

Sobre la regulación de las áreas de protección arqueológica y paleontológica, vid. Javier BERMÚDEZ SÁNCHEZ, El derecho de propiedad: límites derivados de la protección arqueológica, 2003; "Intervenciones arqueológicas en actuaciones urbanísticas: supuestos difíciles", Revista de Derecho Urbanístico y Medio Ambiente, $n^{\circ}$ 47, 2009, pp. 67-86.

"Tampoco consta en los autos que el instrumento de planeamiento impugnado vulnere la Ley de Patrimonio Histórico, sobre esta cuestión se indica que conforme se expone en el informe de la Comisión Territorial de Patrimonio Cultural de 12 de febrero de 1998 que figura incorporado a los autos, la zona afectada por el proyecto no está declarada Bien de Interés Cultural ni se encuentra dentro del entorno de ningún B.I.C., únicamente se ubica dentro del Conjunto Histórico de Salamanca afectado por la disposiciones del Plan Especial de Protección y Reforma Interior del Conjunto Histórico de Salamanca(PEPRI). Por lo anterior, se añade en dicho informe, que la actuación en dicha zona no es un supuesto de autorización previa y preceptiva de la Comisión Territorial de Patrimonio Cultural en aplicación de la Ley 16/1985 del Patrimonio Histórico Español. Todo lo más, se añade, y según lo dispuesto en el Decreto 273/1994, 
que sí anulará la licencia por carecer de proyecto de compensación (sistema de gestión determinado por el PEPRI) que no se puede considerar sustituido por el convenio suscrito entre las partes (FD 3. ${ }^{\circ}$ ).

No todos los bienes tendrán la misma protección, y esto se enmarca en la pertinente modulación de diferentes grados de protección en las diferentes zonas del conjunto que en su caso podrá estar precisado en el plan especial (expresamente en general el art. 21. 1 LPHE que establece protección diferenciada entre otros para los bienes con protección singular ${ }^{84}$ ). Así, las prohibiciones literales de afectar a las alineaciones y volúmenes y edificabilidad, que se ha expuesto (art. 21, apdos., 2 y 3, LPHE), se deberían interpretar además en atención a los diversos grados de protección del conjunto que haya previsto el plan especial ${ }^{85}$.

\section{VALORACIÓN FINAL}

1.- La tensión entre la conservación entendida como mantenimiento estricto de la trama urbana, de un lado, y la mejora de la habitabilidad u operaciones de rehabilitación de los conjuntos históricos, se ha trasladado a la legislación de patrimonio cultural del Estado y las Comunidades Autónomas. El

de 1 de diciembre, sobre competencias y procedimientos en materia de Patrimonio Histórico de la Comunidad de Castilla y León, cabría emitir un informe de asesoramiento a la Universidad de Salamanca encuadrable en la función que le atribuye el art.9.1 de la citada norma. En otro punto del informe se indica que visto el resultado de la excavación los restos descubiertos no poseen entidad suficiente para proponer su declaración como B.I.G. En consecuencia dado el contenido de este informe, que no ha sido desvirtuado en este proceso, no se aprecia la nulidad invocada por la parte actora alegando que en el Estudio de Detalle no se contemplan las prevenciones que sobre los restos de la excavación se efectúan en el citado informe de la Comisión Territorial de Patrimonio Cultural.

Por tanto no apreciándose que concurra ninguno de los motivos de nulidad del Estudio de Detalle invocados por la parte actora en la demanda procede desestimar en este punto el recurso." (FD 2. ${ }^{\circ}$ in fine).

La protección singular no se debe referir aquí a los BIC, como señaló M. BASSOLS COMA, "Instrumentos legales de intervención..., $R D U \mathrm{n}^{\circ}$ 118, ob. cit, 1990, pp. 13-51, en concreto, p 496.

Lo que confirma la crítica a la STSJ de Castilla y León de 5-5-2006, que permite la supresión de una calle en la confluencia con la Plaza Mayor de Soria, frente a las alegaciones del Colegio de Arquitectos. 
tratamiento que esta cuestión recibe en las diversas normas se debe abordar teniendo en cuenta la peculiaridad de esta competencia, que tanto la doctrina como el Tribunal Constitucional (STG 17/1991) han calificado como concurrente, a partir del art. 149. 1. 28. ${ }^{\mathrm{a}}$ y más en concreto art. 149. 2 de la Constitución. La STG 17/1991 ha observado cómo la competencia del Estado incluye la legislativa de dar un tratamiento general, una definición unitaria del patrimonio cultural como tratamiento general en la materia, lo que en esencia, se ha traducido en la posibilidad llevar a cabo remodelaciones urbanas mediante plan especial y la prohibición de sustitución de inmuebles con modificación de alineaciones (LPHE), y las Comunidades Autónomas expresamente permiten la modificación de alineaciones en las operaciones de remodelación urbana. Ahí radica la posible colisión entre ambos legisladores en esta competencia concurrente.

Este es además uno de los puntos más trascendentes del supuesto que se analiza: si realmente se estuviera en presencia de concurrencia de normas válidas se resolvería acudiendo a la regla de la prevalencia del art. 149. 3 de la Constitución, único supuesto en el que a mi juicio se plantea una verdadera prevalencia, a pesar de que el Tribunal Constitucional hasta ahora ha aludido en otros casos a la prevalencia del interés del Estado sobre el de las Comunidades en los supuestos de concurrencia de competencias sobre un espacio fisico, perífrasis que a mi juicio no engloba verdaderos supuestos de reglas válidas sino de problemas de delimitación de materias competenciales, cuya solución pasa por una asignación precisa de contenidos a objetos competenciales diversos, esto es, no hay dos normas válidas, sino que alguna se excede de su objeto competencial, por lo que debe anularse por tal motivo y no por la regla de prevalencia. A ello se añade la competencia ejecutiva del Estado sobre expolio que en el caso del $\mathrm{Ca}^{-}$ banyal plantea nuevos problemas: la Comunidad Autónoma ha dictado normas de caso único declarando el supuesto como respetuoso con la protección del Conjunto.

2.- El plan especial es, según la regulación, el elemento clave en la vertebración de ese régimen jurídico de los Conjuntos, plan que como el resto de planes especiales, se recordará, puede modificar los elementos no estructurantes del Plan General.

3.- La solución que aporta el legislador antes del plan especial de protección impide modificar las alineaciones o la edificabilidad (art. 20 LPHE). La legislación de las Comunidades Autónomas persigue la misma protección salvo, tal vez, el art. 35. 2 de la LPCVa, que en ausencia de plan especial se remite a los criterios de los arts. 38 y 39 de la Ley, precisamente sobre planes espe- 
ciales, esto es, mediante esa remisión parece que podría autorizarse por la Consellería la modificación de alineaciones y volúmenes sin plan especial que se permite también en los planes especiales. Al margen de esa excepción de Valencia, el supuesto ha sido controlado por los Tribunales, entre otros por STSJ de Cantabria de fecha 5 de septiembre de 1997, STS de 4 de octubre de 2001 y STSJ de Islas Baleares de 4 de febrero de 2009. En los entornos, el silencio de la LPHE (que se refiere en general a los Conjuntos sin especificar más) ha sido completado por la legislación de las Comunidades en algunos casos, que sólo refieren tales prohibiciones respecto al Conjunto y excluye a los entornos, que les dota de regulación específica (v. gr. art. 35. 3 LPCCat, que impide obras que perturben la visualización del bien). Alguna salvedad en este sentido sería el art. 33 LPCMa, que expresamente incluye a los entornos en estas prohibiciones.

Alguna sentencia del Tribunal Supremo resulta llamativa o mejor extraña a la solución legal, a mi juicio, en este ámbito de protección, en concreto la STS de 18 de diciembre de 2001, sobre el caso de la intervención sobre el atrio de los Jerónimos en Madrid, un entorno de Monumento en el que sin plan especial se permite modificación de volumen. El Acuerdo del Ministerio de Cultura que se impugna (que es el competente en ese caso por un convenio específico que le atribuye la gestión) se produce antes del plan especial por lo que no era posible modificar las alineaciones, rasantes ni edificabilidad. El TS fundamenta, con cierta apariencia formal pero contra legem a mi juicio, que sí es posible porque ese Acuerdo ordena que se inicie la tramitación del plan, con lo que se evitaría tal prohibición.

4.- A partir de la aprobación del plan especial es cuando el supuesto paradójicamente se complica: en el apdo. 2. ${ }^{\circ}$ del art. 21 LPHE, se permiten operaciones de remodelaciones urbanas en el caso de que impliquen una mejora de sus relaciones con el entorno territorial o urbano o eviten usos degradantes para el propio Conjunto, pero, a su vez, el apdo. $3 .^{\circ}$ establece del mantenimiento de la estructura urbana y arquitectónica y en consecuencia impone que las sustituciones de inmuebles sean excepcionales y contribuyan a la conservación del Conjunto, y de las alineaciones. La complejidad (la desafortunada redacción legal) reside en averiguar si ese precepto impone una prohibición general de modificación de alineaciones (apdo. $3 .^{\circ}$ ) que se exceptuaría en el caso de planes especiales de remodelación que contribuyan a la conservación del Conjunto (supuesto apdo. $2 .^{\circ}$ ), o si está permitiendo sólo las remodelaciones que no supongan modificación de alineaciones. Esas son las dos posibles interpretaciones, que convierten este en un caso dificil del Derecho administrativo. Otra posibilidad es que en la más pura interpretación, se consideren sólo permitidas 
las remodelaciones con modificación de las alineaciones que recuperen la trama urbana, porque éstas no modifican alineaciones históricas.

A mi juicio esta complejidad ha sido interpretada razonablemente en el primer sentido por la legislación de las Comunidades Autónomas, que en general permite remodelación expresamente con modificación de alineaciones en supuestos excepcionales siempre que contribuyan a la conservación general del Conjunto (art. 35. 2 LPCGat, como punto de partida del resto de normas; art. 42. 4 LPCGyL; o art. 39 LPGVa).

5.- La jurisprudencia del TS parece ser oscilante y en algunos casos, según mi criterio, poco afortunada en su solución. Las sentencias más significativas son las siguientes. La STS de 8 de mayo de 1989 (barrio del Velluters o del Pilar, Valencia, y con base sólo en la LPHE pues aún no estaba vigente la LPCVa) permite la modificación de alineaciones que no afecten a la "trama histórica", que erróneamente, a mi juicio, identifica con la estructura fundamental, confundiendo así el límite al plan especial de protección y en su caso de reforma interior en los conjuntos históricos, con el límite de la modificación del plan general por el especial. Frente a esa lectura del art. 21 LPHE que en definitiva permite la modificación de alineaciones, la STS de 5 de marzo de 1999 (calle Céspedes, barrio de Sta. Cruz, Sevilla), sin embargo, impide una mínima modificación en la alineación de esa pequeña calle que impide en su último tramo la circulación de vehículos salvando los edificios colindantes. El Tribunal es contundente en la aplicación literal del art. 21. 3 LPHE, pero al menos coherente con ese precepto, en los mismos términos que la precedente STSJAnd de 31 de julio de 1992. Parece entonces que en ese caso no se admite la interpretación del apdo. $2 .^{\circ}$ como excepción al 3. ${ }^{\circ}$, del art. 21 LPHE. A partir de la aprobación de las normas autonómicas referidas, se han pronunciado un TSJ y dos SSTS admitiendo la modificación de alineaciones mediante plan especial. La STSJCyL de 5 de mayo de 2006 sobre la ampliación del edificio de la Casa Consistorial de Soria con supresión de la calle Teatro, porque con base en la norma comunitaria (CA) a juicio del Tribunal contribuye a la mejora o conservación del Conjunto, y en términos similares las SSTS de 12 y 13 de marzo de 2008 sobre el caso del Cabanyal en Valencia. Tal vez la escusa de estos Tribunales sea la regulación de la Comunidad respectiva, aunque el Supremo parece considerar que no sólo ya que niega además que se vulneren los precedentes judiciales alegados por la demandante.

6.-- Según mi criterio, estas normas de las Comunidades Autónomas no vulnerarían la regulación estatal, aunque podrá ser difícil precisar ese supuesto legal de la LPHE, de remodelaciones en planes especiales que excepcionalmente permitan la modificación de alineaciones si contribuyen a la mejora del 
Conjunto. Podría interpretarse estrictamente como recuperación de la trama histórica, aunque considero que la deficiente regulación estatal tiene una lectura razonable si se interpreta como la legislación de las Comunidades Autónomas, como un supuesto excepcional (del apdo. 2. ${ }^{\circ}$ del art. 21. 3 LPHE frente al supuesto general del art. 21.3. $\left.{ }^{\circ} \mathrm{LPHE}\right)$ que permite las modificaciones de alineaciones que contribuyen a la conservación del Conjunto, pero en todo caso se tiene que fundar cómo contribuyen a la mejora de la conservación del Conjunto: entiendo que también en otros supuestos excepcionales por causas puntuales de rehabilitación de viviendas carentes de servicios o con población en riesgo de exclusión social, por ejemplo, que requieren tal intervención puntual, mínima y en ese sentido excepcional. En consecuencia no habría que recurrir a la regla de la prevalencia en caso de que se planteara ante el TC.

7.- A mi juicio, esos casos de Soria (Casa Consistorial y calle Teatro) y Valencia (el Cabañal), vulneran la legislación estatal y la comunitaria (CGAA), puesto que en ninguno de ellos se puede justificar razonadamente que tales remodelaciones en planes especiales contribuyen a la mejora del Conjunto. La ampliación de la Casa Consistorial será beneficiosa para los intereses de gestión del Ayuntamiento en su caso, pero no para la trama en la misma plaza Mayor de Soria, cuya peculiaridad fue puesta de manifiesto por el Colegio de Arquitectos de Soria. Asimismo, la prolongación de la avenida Blasco Ibáñez a través del barrio del Cabanyal mejorará la comunicación de la ciudad con el mar, de la zona nueva que ha vivido de espaldas al mar, del urbanismo de la ciudad, de sus intereses turísticos, pero no evidentemente del Conjunto. En este sentido no comparto las decisiones del TSJCyL ni del TS, citadas.

8.- En el caso de el Cabanyal, además, se da la peculiaridad de que el Estado ejerce una competencia ejecutiva contra el expolio. Frente a ella, la Comunidad declara primero en Decreto-Ley y después en una Ley que el plan especial no afecta a la conservación del Conjunto. Esa Ley, que pretende nada menos que resolver la aplicación del supuesto legal de mejora de la conservación del Conjunto e impedir así la competencia ejecutiva del Estado, a mi juicio, sí vulnera la legislación del Estado, la posible interpretación constitucional del art. 21 LPHE, pues califica como conservación lo que sin duda no es admisible en el art. 21 LPHE se interprete como se interprete, también en el sentido algo más amplio aquí defendido que el de la mera conservación de la trama histórica. Tal vez, esta Ley y Decreto-Ley dictados para intentar blindar el caso, va a derivar en que en la impugnación ante el Tribunal Constitucional éste tenga que pronunciarse sobre el supuesto y en su caso la prevalencia de la legislación estatal, que impide una actuación con modificación de alineaciones que afecten a la conservación del Conjunto, como es el caso. 